\title{
There is no Target Oriented Speaking Activity without Motivation: Peculiarities of Children's Monologues Expressions*
}

\section{Без мотиву не буває цілеспрямованої мовленнєвої активності: своєрідність дитячих монологічних висловлювань **}

\section{Larysa Kalmykova}

Dr. in Psychology, Professor, Head of the Department of Psychology and Pedagogy of Preschool Education

\section{Лариса Калмикова}

доктор психологічних наук, професор, завідувач кафедри психології і педагогіки дошкільної освіти

\section{E-mail: klo377@ukr.net orcid.org/0000-0002-7538-2635}

Iryna Volzhentseva

Dr. in Psychology, Professor

\section{Ірина Волженцева}

доктор психологічних наук, професор

E-mail: iv.volzhentseva@yandex.ru orcid.org/0000-0003-0458-531X

\section{Nataliia Kharchenko}

Ph.D. in Pedagogy,

Assistant Professor
Наталія Харченко

кандидат педагогічних наук, доцент

\footnotetext{
E-mail: harchenko123@rambler.ru orcid.org/0000-0002-9958-5226

Researcher ID: F-9093-2018
}

\footnotetext{
* This study is done within the framework of the State project and finance support of the Ministry of Education and Science of Ukraine (Registration number 14/17-19).

** Дослідження виконане в рамках Держбюджетного проекту за фінансової підтримки Міністерства освіти і науки України (реєстраційний номер 14/17-19).
} 
Inna Mysan

Ph.D. in Pedagogy,

Assistant Professor

\section{Інна Мисан}

кандидат педагогічних наук, доцент

E-mail: mysan.iv79@gmail.com

orcid.org/0000-0001-9416-4484

Pereiaslav-Khmelnytskyi

Hryhorii Skovoroda State

Pedagogical University

$\triangle$ 30, Sukhomlynskyi Str.,

Pereiaslav-Khmelnytskyi, Kyiv Reg.,

Ukraine, 08401
ДВНЗ «Переяслав-

Хмельнищький державний педагогічний університет імені Григорія Сковороди»

$\triangle$ вул. Сухомлинського, 30,

м. Переяслав-Хмельницький, Київська обл., Україна, 08401

Original manuscript received September 16, 2018

Revised manuscript accepted March 17, 2019

\begin{abstract}
The aim of the article is in the description a) of finding out motivation peculiarities in extended monologue expressions and speech motives of the children of five and six years olds in ontogenesis; b) established connection between development state of speech motives and development state of lexical and grammatical expressions structuring that are out speaking and have great explanation strength while interpreting mastering and owing processes of the native language and oral speech. The used scientific methods are: a) theoretical (analyses of scientific resources, generalization of analyzed literature and its systematization, pointing out of some basic terms, which make the ground of the research, conclusion formulation); b) empirical (playing situations, motivating and speech screening, linguistic contentanalyses of children's judgments, stated, formatting and controlling experiments and survey of children; v) statistics methods. Study of children's monologue expressions was done in terms of speech operations. The results of children's speech observation uncover peculiarities and development levels of Ukrainian speaking children speech motives of five and six years, peculiarities of children's speech motivation typical for every of pointed out levels which witnesses that every child who is developing due to the established criteria has individual and irregular development of motivating and speech operations and actions; highlight the dynamic, vectors and mechanisms of speech motivation development; demonstrate typical strategies of gaining by children meaning formulating motive concepts; gradual development of motive targets, with which appearance we see changing of motive and aim, and speech children's activities epigenetically gain the status of self-estimated and sustainable and goal oriented speech activity; underline operation specific of grammatical structuring of the phrases and extended monologue expressions and selecting words operations according to
\end{abstract}


There is no Target Oriented Speaking Activity without Motivation...

the forms acted by children; confirm correlated analyses interconnections among motivating and lexically grammatical operations.

Key words: speaking motivation, motive-concept, meaning formation, purposeful speaking activity, speaking ontogenesis, speaking competence.

\section{Вступ}

Потреба в мовленнєвому спілкуванні $є$ однією 3 найперших потреб в онтогенетичному розвитку дітей раннього віку. Будучи значущою інтеракційною необхідністю особистості дошкільника, важливою в його психічному розвитку, потреба в комунікації визначає основні вектори становлення видів i форм мовлення в дошкільні роки. Успішне задоволення комунікативних потреб сприяє виформовуванню мотивів, які зумовлюють вербальне самовираження: бажання експлікувати свою думку, формулювати іiі в доцільній - зрозумілій співрозмовниками формі.

Пошук наукових джерел, присвячених проблематиці розвитку мовленнєвих потреб і мотивів на дошкільному етапі мовленнєвого онтогенезу й аналіз статей, опублікованих у відомих світових i вітчизняних журналах, засвідчили відсутність досліджень, які стосувалися б розвитку мотивації й мотивів мовлення дітей дошкільного віку. Більше того, здійснений нами аналіз наукових джерел iз психолінгвістики i психології дав змогу виявити, що взагалі не існує сучасних вітчизняних i зарубіжних наукових розвідок, які висвітлювали б фундаментальні і прикладні аспекти проблематики мовленнєвих мотивів. Спроби знайти в науковій літературі витоки мотиваційно-мовленнєвої проблематики привели нас до публікацій класиків психології, в яких мотивація мовлення скоріше ставиться й актуалізується у зв’язку 3 моделюванням процесу породження мовлення, ніж вирішується в теоретикометодологічному чи емпіричному планах. До цих робіт слід віднести відомі психолінгвістичні праці (Выготский, 2000; Зимняя, 2001; Леонтьев, 1974a, 1974b; Леонтьев, 2003; Лурия, 1998; Рубинштейн, 2000; Ушакова, 2004). Проте окремих наукових статей, присвячених розкриттю своєрідності мотивів висловлювань дітей дошкільного віку та динаміці їх розвитку не знайдено 
також i в класиків психології. Проте поодинокі дослідження, результати яких опубліковані в журналах психолінгвістичного спрямування, стосуються суміжної, тісно пов'язаної з мовленнєвою мотивацією, проблематики комунікативних потреб дітей переважно iз порушенням психофізичного розвитку, зокрема мовлення та спілкування (Gevarter \& Zamora, 2018; Subramaniyan, Nagarajan, Vaidyanathan, et al. 2018; Hui, Lay \& Aznan, 2018; Mandak \& Light, 2018; Mathisen, Bennett, Lockett, Beazley, et al., 2016 та ін.). Але автори зазначених публікацій не торкаються аспектів мотивації й мотивів дитячого мовлення.

Ретельний пошук існуючих наукових джерел і здійснений аналіз змісту наявних у інформаційному науковому просторі публікацій 3 означеної проблеми засвідчують наступне: склалася ситуація, коли феномени «мотиви мовлення» і «мовленнєва мотивація», не будучи власне предметом дослідження психолінгвістики й не отримавши достатньо аргументованого трактування в психології мовлення, залишилися ніби «прикордонними» категоріями, які не знайшли як фундаментального, так і прикладного їх студіювання ні в психології, ні в психолінгвістиці, залишилися поза пріоритетними напрямками дослідження мовлення взагалі, й дитячого, зокрема (якщо не брати до уваги дослідження 3 питань мовленнєвого спілкування, в яких постулюється своєрідність його мотивів (Леонтьев, 1947; Леонтьев, 2003; Лисина, 1974; Ковалев, 1991).

Незважаючи на те, що мотивація мовлення безпосередньо не відноситься власне до породжувального мовленнєвого процесу інтересу й предмету психолінгвістики, але великою мірою зумовлює його перебіг, нами зроблена спроба, враховуючи функції комунікативно-мовленнєвої потреби, а також мовленнєвих мотивів у «формуванні й формулюванні смислів» (Зимняя, 2001), розгортанні внутрішньої програми в зовнішнє мовлення та досягненні мети висловлювання, виявити особливості мотивації дитячих розгорнутих висловлювань і мотивів, характерних для мовлення дітей 5-річного віку, встановити зв'язок між станом розвиненості мотивів мовлення й станом розвитку операцій лексико-граматичного структурування висловлювань. Ці операції, які є зовнішньо-мовленнєвим показником розвитку мовної компетенції дітей цього віку, дозволяє пояснити окремі процеси оволодіння і володіння рідною мовою й рідномовним мовленням в онтогенезі. 
There is no Target Oriented Speaking Activity without Motivation...

Отже, мета статті полягає в презентації методів, методики i результатів мотиваційно-мовленнєвого скринінгу; динаміки, векторів, механізмів і особливостей розвитку операцій виникнення мовленнєвих мотивів, мовленнєвої мотивації й операцій лексикограматичного структурування монологічних висловлювань у дітей п'яти- й шестирічного віку.

\section{Методи і методики дослідження}

Згідно 3 визначеними феноменами передбачено комплекс методів дослідження: теоретичні (аналіз наукових джерел, узагальнення проаналізованої літератури та iï систематизація, виокремлення базових положень, на яких грунтується дослідження, формулювання висновків); емпіричні (ігрові ситуації, мотиваційномовленнєвий скринінг, лінгвістичний контент-аналіз суджень дітей, аналіз граматичних труднощів, лінгвостатистичний метод, констатувальний, формувальний i контрольний експерименти та опитування дітей); статистичні методи (статистичне опрацювання результатів дослідження 3 використанням пакета прикладних програм Statistika-13).

Згідно $з$ тлумаченням мотиву, що є: а) найглибшим початковим моментом формування висловлювання, пов'язаного 3 бажанням більш чітко сформулювати свою думку - концепт (але мотивом висловлювання вважалася й вимога або звернення інформаційного характеру, пов'язане 3 контактом); б) мотивацією, яка породжує мовленнєву інтенцію (Лурия, 1998); в) мовною компетенцією «... сихічною й психофізіологічною функцією людини, закладеною біологічно й генетично, формування й розвиток якої відбувається соціально на основі анатомо-фізіологічної та нейрофізіологічної організації людини; функцією, що забезпечує можливість людській психіці відображати й узагальнювати зовнішній мовний матеріал, переводячи його в особливі внутрішні коди у вигляді неусвідомлюваних й усвідомлюваних правил мови» (Румянцева, 2004: 170) - визначено зміст скринінгу мотивації, мотивів цілеспрямованої мовленнєвої активності й мовної компетенції дітей.

У підгрунтя дослідження, як зазначалося у вступі, покладено уявлення Л. Виготського про фазну будову мовленнєво-мисленнєвого 
процесу (Выготский, 2000); Т.В. Ахутіної про внутрішню генетичну спорідненість мовленнєвих операцій. «Кожна із цих операцій $\epsilon$ реалізацією програми найвищого рівня й виробленням програми для найнижчого. Так, внутрішнє програмування $\epsilon$ реалізацією (об'єктивацією) в певній структурі попередніх етапів мотиву u думки, водночас воно створює програму для лексичного та синтаксичного розгортання» (Ахутина, $2002: 115$ ).

При вивченні онтогенезу мотивів мовленнєвої активності й мовної компетенції дітей орієнтуємося на фундаментальні наукові положення про:

- «системогенезис» (Анохин, 1987), згідно з яким різні елементи системи (в нашому випадку - мовленнєвої) розвиваються нерівномірно: на тлі первинних формуються вторинні, що виконують складніші й більш диференційовані функції (Анохин, 1987);

- «нейропсихологію норми» (Хомская, 2005) та «нейролінгвістику норми» (Ахутина, 2002). У ïx основі лежить уявлення про нерівномірність розвитку вищих психічних функцій у нормі, про індивідуальні відмінності (Ахутина, 1994, 2004a, 2004b; Хомская, 2005);

- «міжіндивідуальну варіабельність», що є не випадковим i небажаним відхиленням від середнього нормативного рівня, а закономірним явищем, вигідним для популяції в цілому; це лише різні, а не погані чи гарні варіанти норми, за Н.В. Дубровинською (Дубровинская, 1996).

Діагностування мотивів мовлення й мовної компетенції дошкільників здійснювали, орієнтуючись на такі експериментально підтверджені Т.В. Ахутіною, Л.В. Яблоковою (Ахутина \& Яблокова, $1993)$ і Н.М. Пилаєвою (Пылаева, 1995) обгрунтовані узагальнення:

- норма характеризується нерівномірністю розвитку вищих психічних функцій, що особливо виразно проявляється в дошкільному віці;

- дисоціації функцій, що спостерігаються, відображають їхню системну будову;

- норма відрізняється від не норми передусім можливостями компенсації функціональних слабостей (Ахутина \& Яблокова, 1993; Ахутина, 2004a, 2004b).

Вивчення мотивів i лексико-граматичного структурування мовлення дітей грунтувалося не тільки на засадах «нейролінгвістики 
норми», а й на «нейропсихологічному підході до діагностики труднощів навчання» (Ахутина, 2004a, 2004b) i зосереджувалося на аналізі як сформованих, так і недостатньо розвинених ланцюгів функціональних систем, що забезпечують дитячу мовленнєву функцію й дають можливість зрозуміти причини неуспішного опанування цілеспрямованою мовленнєвою активністю. Нормативно розвинене мовлення дітей порівнювалося 3 мовленням, яке певною мірою відставало від норми. Таким чином, вивчалася типологія «низької» дитячої норми, що призводить до певних труднощів у навчанні (Ахутина, 2004b).

Емпіричне дослідження проводилося згідно 3 діагностикорозвивальною програмою (Калмикова, 2016) в три етапи:

Перший eman. Констатувальний експеримент: психолінгвістичне обстеження мовлення для виявлення: а) «актуального», досягнутого дошкільниками до п’яти років, рівня розвитку мотивів їхньої мовленнєвої активності й мовної компетенції; б) «потенційного» рівня, пов’язаного із «зоною найближчого розвитку» (Выготский, 2000). Означений скринінг передбачав збір дитячих висловлювань згідно із завданнями дослідження мовленнєвої мотивації, переробку й інтерпретацію отриманих даних, встановлення психолінгвістичного діагнозу та прогнозу, зокрема визначення меж зони найближчого розвитку мотивів дітей шостого року життя, а також перспектив його вдосконалення під впливом навчання.

Другий eman. Формувальний експеримент, спрямований на системний розвиток усвідомленої, навмисної, довільної мовленнєвої активності дітей у зоні їхнього найближчого мовленнєвого розвитку засобами психолінгводидактичних технологій.

Tpemiŭ eman. Контрольний експеримент, що спрямовувався на встановлення ефекту, який передбачався від упроваджених у практику роботи 3 дітьми психолінгводидактичних технологій, тобто виявлення позитивних змін у стані розвиненості мовленнєвих навиків у дітей, які йдуть до 1 класу, а також мотивів мовленнєвої цілеспрямованої активності й мовної компетенції.

До основних завдань вивчення мовлення дошкільників належали такі:

1) виявлення особливостей операцій мотивації мовлення; якісних ознак операцій граматичного структурування мовлення (мовної компетенції); 
2) з'ясування наявності зв'язків між розвитком цих операцій;

3) визначення зони найближчого мовленнєвого розвитку дітей п'ятирічного віку.

Для 3'ясування особливостей і рівнів розвитку мовленнєвих мотивів проведено загальне психолінгвістичне обстеження дітей 5-ти років. Проаналізовано більше 3500 їхніх висловлювань 3 увагою на рівні розвиненості мовленнєвих операцій виникнення мотивації та мовної компетенції й 3'ясування можливостей подальшого розвитку цих операцій у найближчій зоні їх мовленнєвого зростання; визначалися також труднощі мотиваційного й мовного характеру в породженні мовлення в дітей, встановлювалася залежність між станом розвитку в них мотивів монологічних висловлювань і операцій їх лексико-граматичного структурування й вибору слів за формою.

Відповідно до означених теоретичних підходів було вибрано такі показники: а) збуджувальність (спонукання до мовлення, пов'язані із задоволенням потреб мовия); б) предметність (предмет, що спонукає та визначає вибір спрямованості мовленнєвої активності); в) усвідомлюваність (усвідомлювана причина, щэо лежить в основі мовленнєвих вчинків); г) стійкість і самостійність мотивів; г) функціонально-смислові типи висловлювань; д) види речень; е) слова за частинами мови в реченнях; є) розподіл членів речення; ж) розподіл частин мови при вираженні головних $i$ другорядних членів речення; 3) вживання членів речення за способами їх вираження; и) співвіднотення логіко-граматичних членів речення в дитячому мовленні; і) функціонування відмінків у мовленнєвих структурах.

Методики скринінгу орієнтовані на виявлення стану розвитку й специфіки операцій мотивації мовлення й операцій лексикограматичного структурування висловлювань у дітей п'ятирічного віку та визначення зони їхнього найближчого мотиваційного та мовленнємовного розвитку.

3 метою з'ясування особливостей операцій виникнення в дітей мотивів, що збуджують мовленнєву активність, а також визначення предмета потреби дошкільників використано такі методи й методики: 1) створення ситуацій вибору для визначення мотивів; 2) безпосереднього психодіагностування мотивів, що виникли; 3) проективні методики (конструювання й доповнення) 
застосовувалися для діагностування мотивації та вивчення операцій лексико-граматичного структурування фраз i висловлювань а) метод якісного й кількісного аналізу речень i висловлювань, побудованих дітьми; б) метод кількісного аналізу граматичних труднощів; 3) лінгвостатистичний метод.

Насамперед, у процесі мотиваційного скринінгу залучалися методи створення ситуації вибору, оскільки треба було виявити тих дітей, які обрали серед запропонованих видів дитячої активності саме мовленнєву. 3 огляду на це була застосована ігрова ситуація «Біржа праці»: у ході іiі реалізації вихователь брав на себе роль роботодавця, а діти обирали професії та уявно «працевлаштовувалися» на роботу. «Вакантними» виявилися місця лікаря, будівельника, диктора телебачення для ведення передачі «На добраніч, малюки» (з метою розповіді казочки).

Далі використовувалися методи безпосереднього психодіагностування мотивів. Дітям пропонувалися різні за значущістю мотиви. Респонденти мали обрати з них ті, які були для них найбільш значущими. Через безпосередність дітей повністю знімалася проблема зниження правильності й реальності їх відповідей унаслідок можливої дії чинника соціальної бажаності або захисної мотивації. У результаті було з'ясовано те, що зумовлювало вибір дітьми цілеспрямованості мовленнєвої активності. (Перелік мотивів. Ти розповів (-ла) казку, склала для малят розповідь: а) щоб вона сподобалася дітям; б) щоб вона була цікавою для дітей; в) тому що подобається говорити, складати казки, небилиці; г) тому що подобається висловлюватися перед товаришами; щоб тебе слухали й розуміли; д) тому що хочеться навчитися більш чітко висловлювати свою думку).

Враховувалися при аналізі аргументів вибору дітьми із запропонованих їм варіантів мотивів названі й обгрунтовані ними мотиви, тобто самостійні судження й міркування дітей, чому вони обрали той чи інший мотив. Це дало можливість урахувати імпліцитні, не враховані методикою скринінгу, нюанси.

Проективні методики (конструювання й доповнення) спрямовувалися на визначення мотивації. 3 цією метою дітям (за їхнім бажанням) пропонувалося доповнити i по-різному закінчити цікаву історію, початок якої розповів вихователь, а також 
за серією сюжетних картинок, даних у роздріб, скласти розповідь, попередньо виклавши картинки в логічній послідовності.

Після цього проводилося опитування дітей, що мало на меті 3'ясувати: а) чи пов'язані спонукання експериментатора до мовлення дітей із задоволенням потреб дитини-мовця. (Запитання дітям: «Що було б для тебе краще: розповідати чи робити щось інше?»); б) чи усвідомлюють діти причину, що лежить в основі мовленнєвих вчинків? (Запитання дітям: «Чому ти погодився (-лася) складати розповіді?»; в) наскільки стійкі мотиви? (визначалися на підставі того, як діти виконали завдання та чи розкрили достатньо тему висловлювання).

Ураховувалися й самостійні судження дітей, якщо вони виникали. Наприклад: «Буду говорити, як Оля» або «Подобається говорити, щоб краще за Колю» і под. Усі висловлювання дітей записувалися на диктофон, аби зберегти при аналізі автентичність їхнього мовлення. Було використано метод контент-аналізу для вимірювання мотивації цілеспрямованої мовленнєвої активності дошкільників. Спільно 3 підрахунком балів визначалося: чи має розповідь дитини характер орієнтації на досягнення результату у висловлюваннях. Методики якісного й кількісного аналізу речень i висловлювань, побудованих дітьми, кількісного аналізу граматичних труднощів використовувалися для обсервації операцій лексикограматичного структурування дитячих висловлювань.

\section{Результати теоретичного дослідження}

Думка, як стверджував Л.С. Виготський, ніколи не дорівнює прямому значенню слів. Значення опосередковує думку на іï шляху до зовнішнього словесного вираження. Проте в психологічному аналізі висловлювання можна тільки тоді зробити логічний висновок, якщо відкривається останній i найпотаємніший внутрішній план мовленнєвого мислення: його мотивація, оскільки думка народжується не з другої думки, а з мотивуючої сфери свідомості, яка охоплює $i$ захоплення, $i$ потреби, ци інтереси, $i$ спонукання, ŭ афекти, й емочіï людини (Выготский, 2000 : 506). Мотивацію думки Л.С. Виготський образно уподібнює вітру, що рухає хмарки. Дійсне й повне розуміння думки інших стає можливим тільки тоді, 
коли людина розкриває їі справжню приховану причину. «За кожним висловлюванням, - стверджував учений, - стоїть вольове завдання» (там само). За Л.С. Виготським, мотив посідає перше місце в схемі мовленнєпородження: 1) мотив (оформлення думки); 2) думка (опосередкування думки у внутрішньому слові); 3) внутрішнє мовлення (опосередкування в значеннях зовнішніх слів, перехід до синтаксису значень); 4) семантичний план (опосередкування в словах, перехід від синтаксису значень до словесного синтаксису); 5) зовнішнє мовлення. Отже, перша ланка утворення мовлення це його мотивація. Розглядаючи мотиви становлення мовлення, психолог виявляє прямі відношення між мотивом і мовленням, які i $\epsilon$ «відчуттям завдання», «наміром» (там само).

Згідно з С.Л. Рубінштейном саме завдяки мотивам і цілям, що визначають мовлення як акт усвідомлюваної цілеспрямованої активності, фіксуються узагальнені значення, що систематизують суспільний досвід, i набувають індивідуального значення або смислу, в якому відображається особисте ставлення мовця, не стільки його досвід, скільки переживання в нерозривній єдності, що склалися у свідомості індивіда (Рубинштейн, 2000).

Мовленнєва довільна активність актуалізується потребою станом, як його називав С.Л. Рубінштейн, «нужди» в певних умовах нормального функціонування індивіда. Потреба зумовлюється переживанням дискомфорту, незадоволеності, напруги та проявляється в пошуковій активності. Під час цього процесу відбувається поєднання потреби 3 iї предметом, тобто фіксація на предметові, що може іiі задовольнити. 3 цього моменту активність стає спрямованою, потреба опредмечується (як потреба в чомусь конкретному), стаючи мотивом, який може усвідомлюватися (там само).

Шляхи, які проходить мовлення від думки до розгорнутого мовлення, i етапи, які проходить психічний процес людини, що формулює думку, О.Р. Лурія представляє в такій схемі мовленнєвиробництва: людина, яка звертається до іншої людини або хоче викласти свої думки в розгорнутій мовленнєвій формі, має, передусім, мати відповідний мотив висловлювання. Ним може бути бажання сформулювати потребу, виразити прохання, вимогу, які співрозмовник має виконати; в такій ситуації висловлювання буде мати дійовий прагматичний характер. Його мотивом може бути 
передача інформації, входження в контакт 3 іншою людиною, a, можливо, і з’ясування будь-якого явища для самого себе. У даному випадку висловлювання набуває когнітивного, інформаційного характеру. Інколи мотивом може слугувати вираження будь-якого емоційного стану, зняття внутрішньої напруги, тоді воно матиме характер афективних розрядів у формі поклику, вигуку. Мотив висловлювання $є$ лише «відправним пунктом», рушійною силою усього процесу. О.Р. Лурія, виділяючи мотив-контакт і мотивконцепт, пропонує схему механізму створення висловлювання серед яких мотив є першим компонентом (Лурия, 1998).

О.О. Леонтьєв багаторівневий процес побудови висловлювання моделює, починаючи з мотивації, яка породжує думку (мовленнєву інтенцію). На цьому етапі мовець має «образ результату» (Миллер, Галантер \& Прибрам, 1965), але ще відсутній План дії, який він має виконати, щоб його отримати (Леонтьев, 1970 : 28; Леонтьев \& Рябова, 1970).

Мовленнєва діяльність як самодостатня має місце лише тоді, коли мовлення самоцінне, коли мотив, що лежить у його основі та спонукає до реалізації, не задовольняється іншим способом, окрім мовленнєвого: скажімо, професійна ораторська діяльність.

Усі моделі мовленнєпородження, як зазначав О.О. Леонтьєв, досить близькі та, по суті, більше доповнюють і уточнюють, ніж суперечать одна одній. Усі вони відображають єдиний напрям щодо тлумачення цих процесів (Леонтьев, 2003).

Джерелом усіх видів цілеспрямованої мовленнєвої активності $\epsilon$, вважає I.О. Зимняя, комунікативно-пізнавальна потреба, яка реалізується в предметові довільної мовленнєвої активності думці - і стає внутрішнім комунікативно-пізнавальним мотивом цих видів активності. Мотиваційно-збуджувальна фаза цілеспрямованої

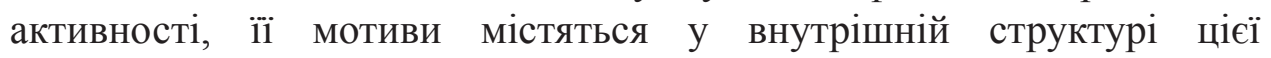
активності, визначають і спрямовують їі (Зимняя, 2001).

\section{Результати емпіричного дослідження}

У процесі аналізу стану розвитку мовленнєвих потреб дошкільників як вихідної форми цілеспрямованої мовленнєвої активності з'ясовано, що із 637 дітей, яких було залучено до 
There is no Target Oriented Speaking Activity without Motivation...

участі в діагностуванні, лише 11,6\% (n=74) дошкільників мали стан об'єктивної нужди в ідеальному предметові - вираженні думок при говорінні, що номінується як мовленнєва потреба. Решта респондентів $(88,4 \%, \mathrm{n}=563)$ мали потребу в матеріальних предметах, необхідних для реалізації своєї життєдіяльності, зокрема потребу в іграх, в іграшках для нібито будівництва житлового будинку (41,5\%, n=264) і лікування хворих (46,9\%, n=299).

Результати аналізу засвідчують, що більшість дітей ще не мають стану об'єктивної нужди в ідеальному предметові оприлюдненому вираженні думок, що $\epsilon$ неодмінною умовою його нормативного функціонування й виступає мовленнєвою потребою, динамічним утворенням, що організує та спрямовує власне мовленнєво-породжувальні i безпосередньо пов'язані 3 ними психічні процеси (перцептивні образи подій, ситуацій; образи уяви, пам'яті, мислення тощо). Відсутність мовленнєвих потреб формувати й розгорнуто виражати особистісні смисли у $88,4 \%$ (n=563) дітей засвідчує відсутність у їхніх висловлюваннях мотивації смислоформулювання, а відтак - цілеспрямованості, а також внутрішнього програмування мовлення, що унеможливлює повноцінне вербальне самовираження. Саме тому задоволення комунікативно-мовленнєвих потреб у цих дітей відбувається лише через діалогічний спосіб в інших, не мовленнєвих видах активності, який здебільшого не потребує цілеспрямованості мовлення, його внутрішнього програмування, розгортання внутрішньо-мовленнєвої програми в зовнішньому мовленні.

Значно менше дітей $(11,6 \%, \mathrm{n}=74)$, які виявили потребу висловлюватися в ситуації спрямованої на них уваги, показали такі результати при виборі із запропонованих мотивів, найбільш значущих для них (табл. 1).

Дані табл. 1 свідчать, що мовлення 11,6\% (n=74) дітейкомунікаторів полімотивоване. В усіх дошкільників, які виявляли бажання оприлюднено висловлюватися, переважають мотиви, пов'язані: а) по-перше, з бажанням говорити так, щоб їхні розповіді насамперед сподобалися, були схвалені іншими, відповідали дитячим смакам при аудіюванні; виявляли прихильність до дітейслухачів, давали їм можливість пережити стан задоволення від змісту сприйнятого (своєрідне виникнення мотиву самопрезентації); б) по-друге, з можливістю забезпечити комунікантам аудіювальне 
задоволення, тобто своїми розповідями викликати в них інтерес до їх сприймання, актуалізувати в однолітків цікавість, привернути їхню увагу, приваблювати своїм говорінням. 9,9\% $\quad(\mathrm{n}=63)$ дошкільників зупиняються на мотивації симпатії, прихильності до себе, бажання справити на однолітків своїм висловлюванням приємне враження, бути приємними іншим, схожими на диктора, виглядати пишномовним мовцем; віддають перевагу мотивам своєї зовнішньої привабливості для інших, мотивації артистизму, бажанні бути в центрі уваги.

Таблиця 1. Стан сформованості мотивів цілеспрямованої мовленнєвої активності дошкільників, у яких переважає нужда в ідеальному предметові

\begin{tabular}{|c|c|c|c|}
\hline № & Запропонований дітям перелік мотивів & $\begin{array}{c}\text { Кількість дітей, } \\
\text { котрі обрали } \\
\text { запропоновані мотиви }\end{array}$ & $\%$ \\
\hline 1. & Потреба, щоб висловлювання сподобалося малюкам & 74 & 11,6 \\
\hline 2. & $\begin{array}{l}\text { Бажання, щоб висловлювання викликало інтерес } \\
\text { у дітей }\end{array}$ & 74 & 11,6 \\
\hline 3. & Подобається висловлюватися перед однолітками & 63 & 9,9 \\
\hline 4. & Хочеться, щоб слухали й розуміли, що кажеш & 7 & 1,1 \\
\hline 5. & $\begin{array}{l}\text { Хочеться більш чітко й точно висловлювати те, } \\
\text { що хочеться розповісти }\end{array}$ & 4 & 0,63 \\
\hline
\end{tabular}

$1,1 \%$ (n=7) дітей пов'язують обрані мотиви 3 ідеальним предметом - забезпечити смислоформування, яке об'єктивно виникає в слухачів при аудіюванні. Це своєрідний неусвідомлюваний дітьмикомунікаторами мотив досягати взаєморозуміння, забезпечувати зворотний зв'язок, актуалізувати «доцільну комунікацію» (Леонтьев, 2003). 0,63\% (n=4) дітей обирають мотиви досягнення - реалізації мети розповіді, а саме: смислоформування і смислоформулювання та пов'язують їх з намаганнями здійснити свої мовленнєві наміри, точніше висловитися, донести свої задуми, розкрити зміст свого мовлення. Це специфічний дитячий мотив, який діти неусвідомлено пов'язують 3 мовленнєвим впливом на комунікантів.

Отже, в $1,1 \%(n=7)$ i 0,63\% (n=4) дітей п’ятирічного віку мовленнєва активність $є$ полімотиваційною, проте в них уже яскраво виражені мовленнєві смислоформувальні та смислоформулювальні мотиви, які засвідчують гіпотетичну цілеспрямованість дитячого 
There is no Target Oriented Speaking Activity without Motivation...

мовлення, їхню мовленнєво-мовну здібність здійснювати мовленнєвий вплив і забезпечувати зворотний зв'язок, спроможність до взаєморозуміння.

У виконанні завдань на конструювання й доповнення брали участь усі 637 респондентів, оскільки вивчалася мотивація мовлення в ситуації, яка потребувала від дітей (за проханням експериментатора) продукувати розповіді за серією малюнків i доповнювати розповіді, розпочаті вихователем. Опитування дітей, проведене після складених розповідей (як вдалих, так і невдалих), засвідчило такий стан розвитку мотивації (табл. 2).

Таблиця 2. Стан розвитку мотивації цілеспрямованої мовленнєвої активності дітей старшого дошкільного віку

\begin{tabular}{|c|c|c|c|}
\hline № & Показники мотивації & $\mathbf{n}=\mathbf{6 3 7}$ & $\%$ \\
\hline 1. & Задоволення потреб дитини в мовленнєвих завданнях. & 140 & 22,0 \\
\hline 2. & Незадоволення потреб дитини мовленнєвими завданнями. & 497 & 78,0 \\
\hline 3. & $\begin{array}{l}\text { Усвідомлення причин, що лежать в основі мовленнєвих вчинків } \\
\text { (зокрема, комунікативних причин і причин, пов'язаних } 3 \\
\text { навчальною діяльністю). }\end{array}$ & 108 & 17,0 \\
\hline 4. & $\begin{array}{l}\text { Неусвідомлюваність причин, що лежать в основі мовленнєвих } \\
\text { вчинків (зокрема, комунікативних причин і причин пов'язаних } 3 \\
\text { навчальною діяльністю). }\end{array}$ & 529 & 83,0 \\
\hline 5. & Стійкість і самостійність мотивів. & 134 & 21,0 \\
\hline 6. & Мінливість мотивів. & 503 & 79,0 \\
\hline 7. & Орієнтація висловлювань на досягнення результату. & 134 & 21,0 \\
\hline 8. & Відсутність мотивації досягнення. & 503 & 79,0 \\
\hline 9. & Несамостійність, але стійкість мотивів. & 70 & 11,0 \\
\hline 10 & Відсутність самостійності. & 567 & 89,0 \\
\hline 11. & Висвітлення теми до логічного завершення - якісне, достатнє. & 198 & 31,1 \\
\hline 12. & Переключення на іншу тематику. & 439 & 68,9 \\
\hline 13. & Відмова від висловлювань. & 64 & 10,0 \\
\hline
\end{tabular}

При визначенні кількісних i якісних показників розвитку мотивації мовлення дітей старшого дошкільного віку орієнтувалися на такі параметри: 1) чи відбувається задоволення комунікативних потреб дітей у мовленнєвих завданнях, чи ні; 2) чи в повному обсязі розкриваються дошкільниками теми розповідей, чи вони в процесі розповідання переключаються на іншу тему; 3) скільки дітей відмовляється продукувати монологічні висловлювання. 
Без мотиву не буває иілеспрямованої мовленнєвої активності...

Аналіз отриманих даних дав можливість зафіксувати наступні результати.

Для 78,0\% (n=497) дітей-респондентів ці завдання не були пов'язані із задоволенням їхніх потреб. Їм краще було б малювати, будувати, переглядати мультфільми, бігати, гратися 3 машинками тощо. 22,0\% (n=140) дошкільників визначили діяльність, що передбачає розповідання, як цікаву й важливу для них справу. $21,0 \%$ (n=134) розвивають обрану тему й не відхиляються від iii розкриття протягом усієї розповіді; 68,9\% $(\mathrm{n}=439)$ дітей не доводять розпочаті розповіді до логічного завершення, змінюють ракурси свого розповідання, відхиляючись від першої теми, переривають висловлювання, не закінчуючи їх, що засвідчує про неусвідомленість причин, які лежать в основі мовленнєвих висловлювань, несамостійність і мінливість мотивів. 10,0\% $(\mathrm{n}=64)$ дітей-респондентів взагалі були нездатні побудувати розповідь. Із 22,0\% (n=140) дошкільників, які задовольняють свої комунікативні потреби в мовленнєвих завданнях, $17,0 \%$ (n=108) дітей усвідомлюють причину, що лежить в основі їхніх мовленнєвих вчинків, пояснюючи іiі аргументами, відповідаючи на запитання: «Чому погодився (-лася) складати розповіді?», таким чином: "Тому, щзо треба навчитися розповідати; тому, щзо треба, щуоб тебе розуміли»; «Хочу бути диктором, бо люблю розказувати казки братику меншому» (Богдана К.); «Хочу бути диктором, щчоб розказувати про футбол» (Назар М.); «Хочу бути диктором, тому щзо папа дивиться телевізор, а мама йому не дає: «Iди митися, іди митися!» А я буду розказувати йому новини, як виросту!» (Настя С.). Решта 83,0\% (n=529) респондентів доводила свої судження неістотними для комунікації аргументами, такими, як: «тому що розповідають інші діти»; «тому щзо подобається виступати перед дітьми, батьками»; «тому щзо я люблю співати й читати вірші»; «щоб командувати й показувати казки»; «тому щуо люблю мультики й казки»; «подобається говорити, бо в мікрофоні голос змінюється», - виявляючи неусвідомленість причин, що лежать в основі мовленнєвих вчинків.

У 21,0\% (n=134) дітей, в яких яскраво виражена потреба в комунікації, спостерігалися стійкі й самостійні мотиви; у 11,0\% (n=70) - несамостійні, але стійкі: вони доводили мовленнєві завдання до логічного завершення, дотримуючись умов їх 
There is no Target Oriented Speaking Activity without Motivation...

виконання. У 79,0\% (n=503) дітей-респондентів спостерігалася мінливість мотивів.

Результати вимірювання (контент-аналізу) мотивації мовленнєвої активності дали змогу з'ясувати, що в $11,0 \%$ $(\mathrm{n}=70)$ дітей спостерігається поєднання («зустріч») потреби в комунікації 3 ii предметом (мовленнєве самовираження) відбувається процес «упізнання» мовленнєвою потребою свого предмета, або опредмечування комунікативно-мовленнєвої потреби (імпринтинг). У цих дітей комунікативно-мовленнєві потреби $\epsilon$ визначеними як потреби саме в цьому предметові - вираженні думок, оприлюдненому говорінні, а не в інших предметах, як це має місце в інших дошкільників, залучених до діагностування. Переказані дітьми казки, цікаві розповіді в телевізійній передачі «На добраніч, малюки», мовленнєві завдання (проективні методики) показали, що в цих дітей в акті опредмечування вже народився мотив, який є предметом комунікативно-мовленнєвих потреб. Через опредмечування ці потреби набули своєї конкретизації: як нужди в оприлюдненому смислоформуванні і смислоформулюванні. Мотив у цих дітей виступає опредмеченою потребою. I саме завдяки опредмечуванню потреби та наявності мотиву в дошкільників докорінно відрізняється тип мовленнєвої поведінки. Їхнє мовлення $\epsilon$ спрямованим, залежним від мовленнєвого мотиву, розповіді зорієнтовані на досягнення результату (мотивація досягнення).

Діагностика операцій виникнення мотивів мовлення дітей п'ятирічного віку дала змогу виявити різнорівневий стан їx розвитку, який умовно зафіксований у вигляді 4-х рівнів.

До першого рівня розвитку операщій виникнення мотиву були віднесені респонденти $(11,2 \%, \mathrm{n}=71)$, в яких яскраво виражений мотив як предмет комунікативно-мовленнєвих потреб, як нужди в оприлюдненому смислоформулюванні; спрямованість їхнього монологічного мовлення залежала від мовленнєвого мотиву, спостерігалася стійкість мотивів, мотивація досягнення. До другого рівня розвитку операцій виникнення мотиву віднесено респондентів $(22,0 \%, \mathrm{n}=140)$, в яких комунікативно-мовленнєві потреби (як необхідність саме у вираженні думок) недостатньо визначені; мовлення полімотивоване; мовленнєвий мотив не досягає рівня розвитку, аби стати опредмеченою потребою; це ступінь розвитку, на якому відбувається саме опредмечування 
Без мотиву не буває иілеспрямованої мовленнєвої активності...

мовленнєвої потреби та набуття конкретизації як нужди в смислоформуванні й смислоформулюванні. Мотиви стійкі, але несамостійні, здебільшого викликані експериментальними або навчальними завданнями. Це стан становлення мовленнєвого мотиву формування й формулювання смислів. До третього рівня розвитку віднесено навики респондентів (49,0\%, $\mathrm{n}=312)$, у яких не виявлено мотивів, що спонукають цілеспрямовану мовленнєву активність; їхнє мовлення полімотивоване, збуджується кількома мотивами, зазвичай, не мовленнєвими, а потреби в комунікації не пов'язуються 3 мовленнєвим самовираженням; комунікативномовленнєві потреби в матеріалізації думок залишаються не визначеними, не конкретизованими. До четвертого рівня розвитку операцій виникнення мотиву віднесено респонденів (17,8\%, n=114), у яких задоволення комунікативних потреб відбувається лише в не мовленнєвих видах активності та в діалогах і полілогах.

Наступний етап констатувального експерименту був пов'язаний із виявленням розвиненості лінгвістичних здібностей цих респондентів і виявленням кореляційних зв'язків між ступенем розвитку мотивів їхнього мовлення та мовною компетенцією ступенем розвиненості операцій лексико-граматичного структурування мовлення.

За результатами лінгвістичного аналізу мовлення 637 дітей, які брали участь у мовленнєвому скринінгу, також було встановлено чотири рівні розвитку операцій лексико-граматичного структурування мовлення.

До першої групи розвитку операцій граматичного структурування було віднесено $11,0 \% \quad(n=70)$ уміння дітей, які володіють різними відмінково-прийменниковими формами. Їх мовлення наближене до контекстного. Обсяг простих речень інколи перевищує 5 слів, а складні речення містять до 8-10 слів, що свідчить про достатній для цілеспрямованого висловлювання в цьому віці розвиток мовленнєвої оперативної пам'яті. До другої групи розвитку операцій граматичного структурування було віднесено $25,9 \% \quad(\mathrm{n}=165)$ респондентів, мовлення яких характеризується достатнім для створення висловлювань рівнем розвитку операцій граматичного структурування. Разом $з$ тим у ньому спостерігаються елементи ситуативності, більш обмежена кількість деяких видів простих і складних речень, зустрічаються помилки при вживанні 
There is no Target Oriented Speaking Activity without Motivation...

окремих відмінків і прийменників, однотипне вираження членів речення. До третьої групи розвитку операцій граматичного структурування віднесено 53,1\% (n = 338) учасників експерименту, які володіють окремими операціями побудови простих і складних речень, проте вони недостатні для розгорнутих висловлювань; мовлення ситуативне, інтонаційно нерозчленоване. Спостерігається недостатнє для вираження смислу володіння відмінками й прийменниками. В реченнях діти, як правило, вживають лише прямі додатки й обставини місця, які виражають одноманітно, оскільки не володіють різними способами їх передавання. Їх мовлення дієслівне, супроводжується використанням великої кількості прислівників. До четвертого рівня розвитку операцій граматичного структурування віднесено 10,0\% (n=64) дошкільників, яким важко актуалізувати слова. Речення, побудовані ними, складаються з 2-3 слів. Складні речення дошкільники майже не вживають. Їхні висловлювання містять 3-4 непоширених або поширених прямим додатком речень. Вони нерідко відмовляються будувати розповіді, відчувають невпевненість у собі, страх, дискомфорт.

Порівняння результатів мотиваційного й мовленнєвого (мовно-компетентнісного) скринінгу засвідчило, що майже всі діти $(11,2 \%, \mathrm{n}=71)$, вміння яких віднесено до високого рівня розвитку операцій мотивації цілеспрямованого мовлення, увійшли в групу респондентів $(11,0 \%, \mathrm{n}=70)$, віднесених до високого рівня розвитку лексико-граматичного структурування висловлювання. Така ж тенденція простежувалася і в показниках інших рівнів (достатній, середній, низький) (рис. 1).

3 респондентами, які брали участь у констатувальному експерименті, було проведено формувальний експеримент за психолінгводидактичннми технологіями (Калмикова, 2016). Оскільки опис цієї системи не був предметом і метою цієї статті, тому в подальшому зупиняємося лише на результатах іiі застосування в роботі 3 дітьми, аби розкрити, як відбувався розвиток мотивів i лексико-граматичного структурування мовлення в дітей на шостому році мовленнєвого онтогенезу під впливом психолінгвотехнологій навчання рідної мови; яких результатів діти спроможні досягти в розвитку мотивів мовлення і мовної компетенції, як ці мотиви починають спрямовувати перебіг дитячого монологічного мовлення та чи детермінують удосконалення їхньої мовної здатності. 

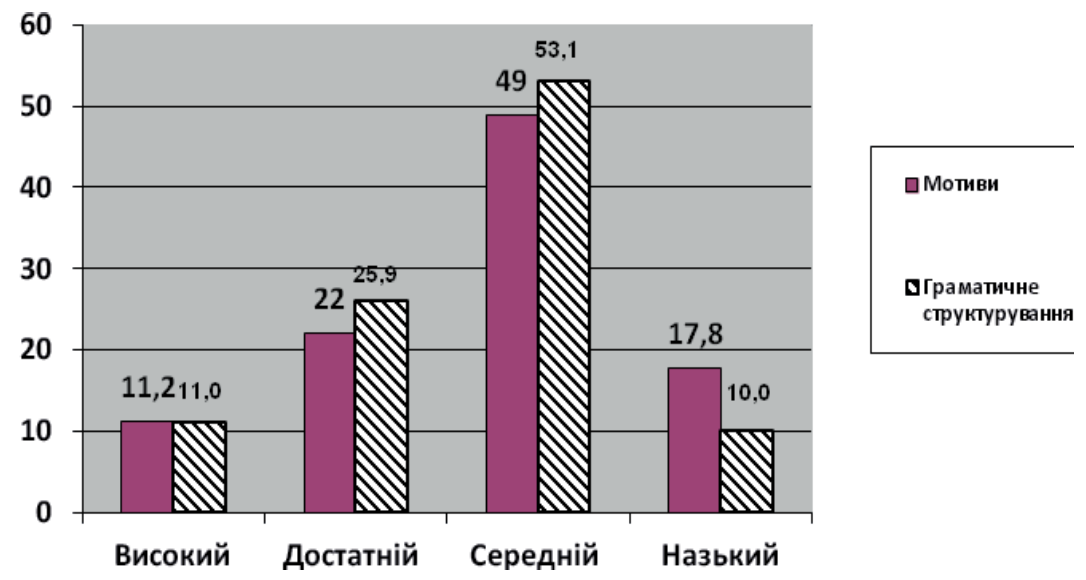

Рис. 1. Розвиток операцій виникнення мовленнєвих мотивів i операчій лексико-граматичного структурування висловлювань

Результати контрольного експерименту, проведеного за методикою первинного мотиваційно-мовленнєвого скринінгу, засвідчили певну динаміку й вектори розвитку в дітей мовленнєвої мотивації, мовної компетенції та сприяли виявленню типологічних особливостей, а також індивідуальних відмінностей у сформованих мовленнєвих операціях. Зафіксовано чотири рівні розвитку в шестирічних дітей мотивів довільної мовленнєвої активності й відповідні до них особливі психологічні характеристики. Виявлено також нерівномірність розвитку в цих респондентів операцій лексико-граматичного структурування монологічного мовлення та їх психолінгвістичні характеристики (див. табл. 3).

Дані таблиці засвідчують, що рівень розвитку цілеспрямованої мовленнєвої активності в дітей $(75,0 \%, \mathrm{n}=478)$, умовно віднесених до I групи, називаємо високим - висхідним. Він $є$ достатнім для продукування усвідомленого, довільного, навмисного монологічного мовлення, продуктивного 3 огляду на реалізацію публічних висловлювань, і перспективним для подальшого розвитку мовленнєвої активності до рівня, який більший від звичайного для дітей иієї групи і який може в майбутньому вдосконалюватися до найвищого рівня. Мовлення респондентів, умовно віднесених до цієї групи, що збільшилася порівняно з даними констатувального експерименту більше як на $60,0 \%$, характеризується сформованістю мотивів, пов'язаних зі смислоформуванням і смислоформулюванням, 
There is no Target Oriented Speaking Activity without Motivation...

а також виникненням нових мотивів - мотивів-цілей. Зрушення в мотиваційній сфері зовнішньо виявлялися в тому, що діти почали отримувати задоволення від того, що висловлюються комунікативно доцільно, граматично правильно, що ініціатива будувати розповіді, описи, міркування вже надходить від них самих. Ускладнилися, набули стійкості й збуджувальної сили i стали метою ті головні смислові мотиви комунікації, які заповнюють позитивними емоціями мовленнєві дії, продуковані дітьми. Усвідомлювані мотиви-цілі, які почали виформовуватися, свідчать про початкове становлення в дошкільників цілеспрямованої мовленнєвої активності.

Таблиця 3. Порівняння результатів розвитку операцій мовлення дошкільників шестирічного віку на етапах констатувального i контрольного експериментів (у відсотках)

\begin{tabular}{|c|c|c|c|c|c|c|c|c|}
\hline \multirow{4}{*}{$\begin{array}{c}\text { Рівні розвитку } \\
\text { операцій }\end{array}$} & \multicolumn{8}{|c|}{ Операції } \\
\hline & \multicolumn{4}{|c|}{$\begin{array}{c}\text { Виникнення мотивів } \\
\text { мовлення }\end{array}$} & \multicolumn{4}{|c|}{$\begin{array}{c}\text { Лексико-граматичне } \\
\text { структурування висловлювання }\end{array}$} \\
\hline & \multicolumn{2}{|c|}{$\begin{array}{c}\text { До } \\
\text { експерименту }\end{array}$} & \multicolumn{2}{|c|}{$\begin{array}{c}\text { Після } \\
\text { експерименту }\end{array}$} & \multicolumn{2}{|c|}{$\begin{array}{c}\text { До } \\
\text { експерименту }\end{array}$} & \multicolumn{2}{|c|}{$\begin{array}{c}\text { Після } \\
\text { експерименту }\end{array}$} \\
\hline & $\mathrm{n}$ & $\%$ & $\mathrm{n}$ & $\%$ & $\mathrm{n}$ & $\%$ & $\mathrm{n}$ & $\%$ \\
\hline Високий & 71 & 11,2 & 478 & 75,0 & 70 & 11,0 & 474 & 74,4 \\
\hline Достатній & 140 & 22,0 & 41 & 6,5 & 165 & 25,9 & 57 & 8,9 \\
\hline Середній & 312 & 49,0 & 67 & 10,5 & 338 & 53,1 & 57 & 8,9 \\
\hline Низький & 114 & 17,8 & 51 & 8,0 & 64 & 10,0 & 49 & 7,8 \\
\hline
\end{tabular}

У $74,4 \% \quad(\mathrm{n}=474)$ респондентів, віднесених до першої групи, спостерігається більший від звичайного за інтенсивністю рівень розвитку зовнішньомовленнєвих операцій (поверхневий синтаксис $\left.{ }^{* * *}\right)$ : дошкільники користуються невеликим за обсягом монологом, будуючи до 7-10 простих і складних речень. Для їхніх висловлювань характерні як зв'язність, так і цілісність, наявність засобів міжфразового зв'язку; досить різноманітна 3 огляду на значення й тематичний склад ужита ними лексика. Їм притаманний достатній для повноцінного спілкування й самовираження

*** Аналіз мовленнєвих операцій у дітей ґрунтується на ідеях Л.С. Виготського про специфіку шляху від думки до слова, на якому кожний його етап має свій особливий синтаксис і семантику (Выготский, 2000); а також Т.В. Ахутіної про наявність трьох видів синтаксису (смислового, семантичного і поверхневого) (Ахутина, 2002).

(C) Kalmykova L., Volzhentseva I., Kharchnko N. \& Mysan I. 
(в межах цього віку) рівень сформованості операцій граматичного структурування та вибору слів за формою, а також зумовлений розвитком мовної компетенції ступінь становлення операцій внутрішнього програмування й вибору смислів і мовних значень слів, які на цьому етапі мовленнєдіяльнісного онтогенезу вже не в такій мірі залежать від операцій граматичного структурування, їх інтеріоризації, як це має місце в ранньому дошкільному віці, a, навпаки, починають зворотно впливати на них: керувати ними, забезпечуючи лексико-граматичне розгортання мовлення.

Рівень розвитку мовленнєвої активності дітей, яких умовно віднесено до другої групи, (меншу за рахунок переходу в першу групу, порівняно з даними констатувального експерименту на 5,9\%), умовно номінуємо як достатній - типовий (нормативний) рівень, якого вистачає для початкової реалізації мовленнєвих дій. Розвиток мовленнєвих мотивів відповідає рівню смислоформулювання. Мотиви усвідомлені ними як навчально-мовленнєві; мовленнєві дії стимулюються або одним провідним смислоформувальним i смислоформулювальним мотивом чи й кількома мотивами одночасно. В дошкільнят цієї групи образ результату їхнього майбутнього висловлювання щільно пов'язується із смислоформулювальним мотивом, набуває збуджувальної сили, а тому стає метою, спрямовуючи зовнішньомовленнєві дії й визначаючи вибір способів і мовних засобів іiі здійснення.

Чимало цих дошкільників $(8,9 \%, \mathrm{n}=57)$ мають i достатній рівень розвитку зовнішньомовленнєвих операцій, але їм важко розгортати висловлювання за правилами поверхневого синтаксису при поширенні простих речень іменними словосполученнями, хоча вони без труднощів будують складні речення, а також розгорнуті, зв'язні й цілісні висловлювання за композицією розповіді, опису, міркування. Якісна характеристика граматичного структурування мовлення дітей, компетенції яких віднесено до другої групи, дає можливість стверджувати, що в них уже практично сформована мовна компетенція стосовно продукування висловлювань у межах 5-8 речень.

Рівень розвитку мовленнєвої діяльності респондентів, включених до третьої групи, визначаємо як середній - досяжний (якого можна досягти), як можливий за певних умов для реалізації мовлених дій, проте нижчий за типовий, нормативний рівень 
розвитку однолітків. У дітей цієї групи мовленнєві дії стимулюються кількома мотивами (навчальними, комунікаційними, ігровими), серед яких наявні й смислоформулювальний і смислоформувальний мотиви, але вони здебільшого не усвідомлюються. Для мовлення дітей цієї групи $(8,9 \%, \quad \mathrm{n}=57)$ характерний низький рівень сформованості лексико-граматичних операцій. Дошкільникам важко поширювати прості речення, вони допускають помилки в побудові складних речень. Їхнє мовлення збіднене щодо синтаксису й морфології. Вони сором'язливі, невпевнені у своїх висловлюваннях. У всіх респондентів, умовно віднесених до третьої групи, фрази недостатньо розгорнуті, тому в їх мовленні переважає використання тільки називного або називного й знахідного відмінків; спостерігається тенденція до скорочення довжини фраз і збільшення частки дієслів і недоречних вставних слів, якими вони заповнюють паузи. Дошкільникам важко актуалізовувати словосполучення, в них, здебільшого, переважає вживання прислівників як другорядних членів речення. Через недостатню сформованість операцій поверхневого синтаксування в дітей спостерігається незначне за обсягом розгортання зовнішньомовленнєвих структур, які містять від 3 до 5 слів. У них яскраво виявляється недостатня для реалізації мовленнєвої дії сформованість мовної компетенції щодо творення розгорнутих висловлювань. Тому і з'являються ситуативні за змістом, недосконалі за формою й граматичним оформленням монологічні висловлювання дітей, хоча й спостерігається мовна здатність не ситуативно оформляти окремі фрази. Зовнішньо ситуативність дитячого мовлення проявляється в необмеженій наявності в ньому займенників і займенникових прислівників, що позначають події. Наприклад: «Коля пішов туди $i$ там знайшов..., а коли вони повернулися... ну... принесли з туда такого... маленького (показус). Потім напоӥли молочком. А воно мявкає, плакає, ...ну шукає там маму» (Андрій Т.). Слова-прокладки, вжиті у висловлюваннях, типу: «туди», «там», «його», «такого» та інші $\epsilon$ «визначеннями мисленнєвого образу» (Ахутина, 2002), адекватність передавання якого потребує досконалого володіння поверхневим синтаксисом, а також доречного вибору словоформ та утворення граматичних структур, тобто лексико-граматичного розгортання семантикосинтаксичних структур за правилами зовнішнього мовлення. Не розгорнуте достатньою мірою зовнішнє мовлення дітей не $\epsilon$ 
абсолютним показником ступеня розвитку мовної компетенції, володіння граматикою рідної мови. Дитячий поверхневий синтаксис належить до активної граматики - прошарку граматичних форм, що функціонують у висловлюваннях. Діти постійно й вільно користуються ними в своєму усному мовленні та розуміють їх основне (інваріантне) значення. Водночас існує пасивна дитяча граматика, значення граматичних форм якої діти розуміють, але ці словоформи не використовують у практиці говоріння. Свідченням існування в ментальному лексиконі дошкільнят пасивних граматичних форм рідної мови та їх ремінісценції $є$ непоодинокі приклади того, як вони легко й вільно відтворюють латентний потенціал у непримусовій ситуації спілкування словосполученнями й реченнями, які не вживаються ними в довільній, скеровуваній активності 3 продукування монологічного висловлювання, яке потребує передусім розвинених смислоформувальних мотивів. Ці факти підтверджують психолого-педагогічне значення формування в дошкільників операцій мотивації мовлення для розвитку більш досконалої логіки граматичного структурування й операцій вибору слів за граматичною словоформою, позитивного впливу на стан мовної компетенції дітей.

Рівень розвитку мовленнєвої активності респондентів, вправність яких віднесено до четвертої групи, номінуємо як низький евентуальний, тобто в перспективі можливий як типовий за певних умов, віртуальний, імовірнісний. Проте насправді це неналежний, недостатній для реалізації мовленнєвих дій, проблематичний, іррегулярний, не релевантний нормам цілеспрямованої мовленнєвої активності рівень. Цей рівень розглядаємо як спорадичний (нестійкий, поодинокий); акцидентний (тимчасовий, минущий) за сприятливих психолінгводидактичних умов.

Для мовлення респондентів, віднесених до цієї групи, що зменшилася, порівняно з етапом скринінгу на 13,5\%, характерні такі ознаки: уперше з'являється потреба в смислоформулюванні (говорити) i смислоформуванні (розуміти інших), дошкільники намагаються зрозуміти причини, що лежать в основі навчальномовленнєвої діяльності, проте їхні мотиви несамостійні, нестійкі, а мовлення залишається полімотивованим, відсутня в достатній мірі мотивація досягнення, успіху, самоствердження, розкриття потенціалу. 
There is no Target Oriented Speaking Activity without Motivation...

У 7,8\% (n=49) дітей, яких умовно віднесено до четвертої групи, спостерігається не сформованість структури фрази, збільшене вживання іменників і дієслів у синтаксичній функції підмета й присудка, незначна кількість прислівників і майже повна відсутність займенників і прийменників, наявність стереотипних фраз і збільшення частки недоречно вставлених слів-прокладок. Ці тенденції $є$ свідченням недостатньої сформованості операцій граматичного структурування, уповільненої в часі, тривалої інтеріоризації і, як наслідок, затримки розвитку мовної компетенції.

Дані про результати мотиваційного й мовленнємовного скринінгу, про кореляційні зв'язки між розвитком операцій виникнення мотивів i лексико-граматичним структуруванням висловлювання представлено в табл. 4. та рис. 2.

Таблиця 4. Результати аналізу розвитку мовленнєвих мотивів і граматичного структурування висловлювань до та після формувальних заходів (у балах)

\begin{tabular}{|c|c|c|c|c|c|c|}
\hline \multirow{3}{*}{$\begin{array}{c}\text { Рівні } \\
\text { розвитку } \\
\text { операцій }\end{array}$} & \multicolumn{6}{|c|}{ Операції } \\
\hline & \multicolumn{3}{|c|}{$\begin{array}{c}\text { Виникнення мотивів } \\
\text { мовлення }\end{array}$} & \multicolumn{3}{|c|}{$\begin{array}{c}\text { Лексико-граматичне } \\
\text { структурування висловлювання }\end{array}$} \\
\hline & До & Після & $\mathrm{Pd}$ & До & Після & $\mathrm{Pd}$ \\
\hline Високий & $11,21 \pm 1,16^{2}$ & $75,01 \pm 9,94^{2}$ & $\mathrm{p} \leq 0,05$ & $11,01 \pm 1,91^{2}$ & $74,41 \pm 8,35^{2}$ & $\mathrm{p} \leq 0,05$ \\
\hline Достатній & $22,0 \pm 2,14$ & $6,5 \pm 0,24$ & $\mathrm{p} \leq 0,05$ & $25,9 \pm 2,07$ & $8,9 \pm 1,67$ & $\mathrm{p} \leq 0,05$ \\
\hline Середній & $49,0 \pm 6,72$ & $10,5 \pm 2,31$ & $\mathrm{p} \leq 0,05$ & $53,1 \pm 5,24$ & $8,9 \pm 1,08$ & $\mathrm{p} \leq 0,05$ \\
\hline Низький & $17,8 \pm 1,28$ & $8,0 \pm 0,64$ & $\mathrm{p} \leq 0,05$ & $10,0 \pm 1,89$ & $7,8 \pm 0,94$ & $\mathrm{p} \leq 0,05$ \\
\hline
\end{tabular}

Умовні позначення і пояснення:

1. Середнє арифметичне значення операцій в експериментальній групі дошкільників до та після розвивально-корегуючого впливу в ЕГ

2. Стандартне відхилення операцій в експериментальній групі в дошкільників до та після розвивально-корегуючого впливу в ЕГ

3. Pd - вірогідність помилкового судження про відмінність порівнюваних середніх розраховувалося на рівні 0,05

Аналіз результатів дослідження дозволяє стверджувати, що запропонований підхід до формування в дітей усвідомленої, навмисної, довільної мовленнєвої активності засобами психолінгводидактичних технологій (Калмикова, 2016) має виражений розвивально-коригуючий вплив на їхній мовленнєвий розвиток (див. табл. 4). 
Без мотиву не буває иілеспрямованої мовленнєвої активності...

Дані таблиці 4 засвідчують, що психолінгводидактичні впливи, здійснені відповідно до розвивальної програми, помітно змінюють виявлені в процесі скринінгу рівні розвитку операцій. Так, порівнюючи операції мотивів мовлення, віднесені до високого рівня до $(11,2 \pm 1,16)$ та після їх формування $(75,0 \pm 9,94)$, необхідно відмітити, що вони вірогідно розрізняються при $\mathrm{p} \leq 0,05$ за $\mathrm{t}-$ критерієм Стьюдента. Операції, віднесені до достатнього рівня до $(22,0 \pm 2,14)$ та після корекції $(6,5 \pm 0,24)$ також достовірно розрізняються при $\mathrm{p} \leq 0,05$, що свідчить про ефективність застосовуваних психолінгводидактичних технологій. Необхідно також охарактеризувати зміни, які відбулися за середнім i низьким рівнями розвитку означених операцій, оскільки зафіксовано зменшення раніше виявлених результатів, а саме: операції, характерні для середнього рівня розвитку до $(49,0 \pm 6,72)$ та після корекції $(10,5 \pm 2,31)$ й операції, характерні для низького рівня до $(17,8 \pm 1,28)$ та після корекції $(8,0 \pm 0,64)$ вірогідно розрізняються при $\mathrm{p} \leq 0,05$. Це свідчить про те, що в дітей 5-ти років на дошкільному етапі онтогенезу з підвищенням рівня розвиненості мотивів мовлення, набуттям таких ознак, як самостійність висловлювань, усвідомлення причин, що лежать в основі мовленнєвих вчинків, зокрема пов'язаних 3 навчальномовленнєвою діяльністю, підвищився й рівень розвитку операцій лексико-граматичного структурування висловлювання.

Тепер детальніше представимо вірогідність отриманих результатів у контексті логічних операцій лексико-граматичного структурування висловлювання. Так, порівняння стану їх розвиненості до та після психолінгводидактичних заходів продемонструвало, що динаміка змін у розвитку мовленнєвого мотиву позитивно вплинула й на розвиток лексико-граматичного структурування висловлювання (див. табл. 4). Як засвідчують дані табл. 4, стан розвитку операцій, віднесених до високого рівня, поліпшився: до впливу при $\mathrm{M}=11,0(\mathrm{~S}=1,91)$ та після впливу при $\mathrm{M}=74,4(\mathrm{~S}=8,35)$ він суттєво відрізняється при $\mathrm{P} \leq 0,05$. Також позитивні зміни зафіксовані й стосовно інших рівнів розвитку операцій лексико-граматичного структурування висловлювання. Так, стан розвитку операцій, віднесених до достатнього рівня, до впливу при $\mathrm{M}=25,9(\mathrm{~S}=2,07)$ та після впливу при $\mathrm{M}=8,9$ 
There is no Target Oriented Speaking Activity without Motivation...

$(\mathrm{S}=1,67)$, а також операцій, віднесених до середнього рівня, до впливу при $\mathrm{M}=53,1(\mathrm{~S}=5,24)$ і після впливу при $\mathrm{M}=8,9$ $(\mathrm{S}=1,08)$ та операцій, характерних для низького рівня, до впливу при $\mathrm{M}=10,0(\mathrm{~S}=1,89)$ та після впливу при $\mathrm{M}=7,8 \quad(\mathrm{~S}=0,94)$ вірогідно розрізняється при $\mathrm{P} \leq 0,05$. Отже, отримані результати свідчать про те, що психолінгводидактичні технології дали змогу підвищити рівні й покращити стан розвитку мотиваційномовленнєвих операцій і відповідно до якісних змін удосконалити операції лексико-граматичного структурування висловлювання.

Для зорового сприйняття отриманих даних подано рисунок 2.

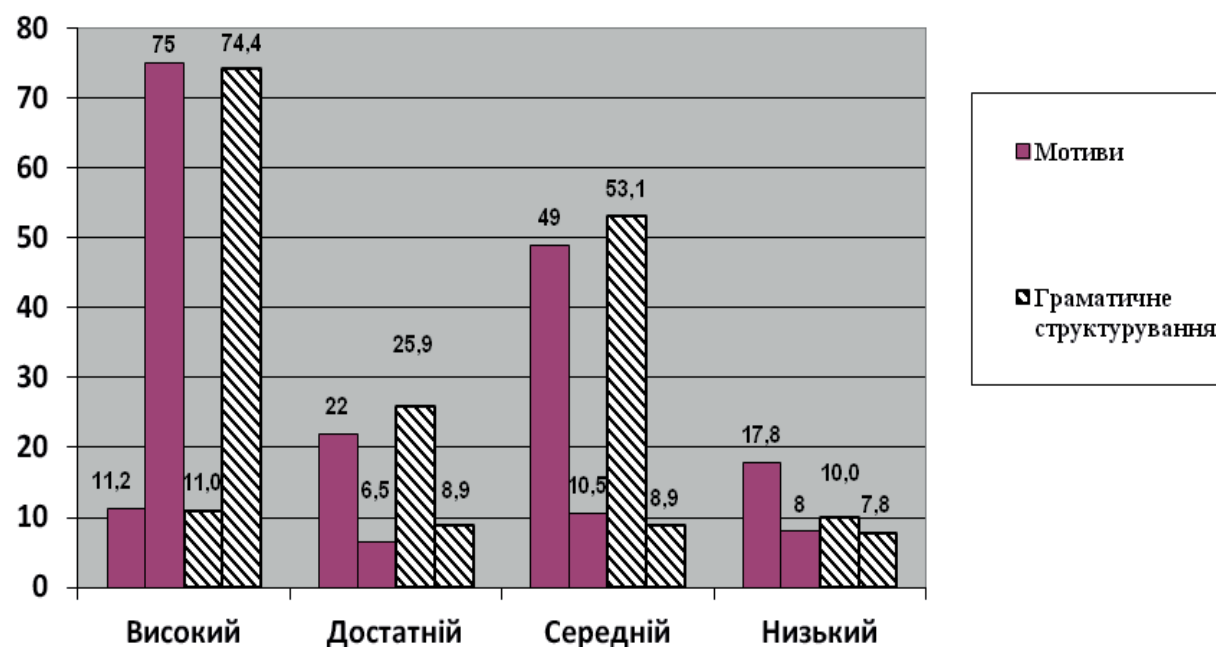

Рис. 2. Стан розвитку операцій виникнення мовленнєвого мотиву й граматичного структурування висловлювань до та після лінгводидактичних технологій за рівнями

Таким чином, експериментально доведено, що результати, отримані до й після формувальних впливів, достовірні за t-критерієм Стьюдента. Розроблена психолінгводидактична система сприяла покращенню стану розвитку операцій виникнення мовленнєвих мотивів i операцій лексико-граматичного структурування висловлювань у дошкільників експериментальної групи.

Аналізуючи отримані результати кореляційного аналізу за допомогою критерія К. Пірсона (див. табл. 5), виявили досить виражену залежність, а саме: а) між високими рівнями розвитку операцій виникнення мотивів мовлення й лексико-граматичним 
структуруванням висловлювання $(\mathrm{r}=0,733)$ на рівні 0,01 , оскільки він більший від критичного значення 0,730, і менший від критичного значення 0,760 при відповідності 0,001; б) між достатніми рівнями розвитку операцій виникнення мотивів мовлення й лексико-граматичним структуруванням висловлювання $(\mathrm{r}=0,707)$ статистично достовірний на рівні 0,01 i менший від критичного значення 0,724 при відповідності 0,001; в) між середніми рівнями розвитку операцій виникнення мотивів мовлення i лексико-граматичним структуруванням висловлювання $(\mathrm{r}=0,683)$ статистично достовірний на рівні 0,01 і менший від критичного значення 0,693 при відповідності 0,001.

Таблиця 5. Кореляційний аналіз розвитку операцій виникнення мовленнєвого мотиву й граматичного структурування висловлювання за К. Пірсоном

\begin{tabular}{|c|c|c|}
\hline \multirow[b]{2}{*}{ Рівні розвитку операцій } & \multicolumn{2}{|c|}{ Операції } \\
\hline & $\begin{array}{c}\text { Виникнення мотивів } \\
\text { мовлення }\end{array}$ & $\begin{array}{c}\text { Лексико-граматичне } \\
\text { структурування } \\
\text { висловлювання }\end{array}$ \\
\hline $\mathrm{X} / \mathrm{Y}$ & $\mathrm{x}$ & $\mathrm{y}$ \\
\hline Високий & \multicolumn{2}{|c|}{$\mathrm{r}=0,733$} \\
\hline Достатній & \multicolumn{2}{|c|}{$\mathrm{r}=0,707$} \\
\hline Середній & \multicolumn{2}{|c|}{$\mathrm{r}=0,683$} \\
\hline
\end{tabular}

Таким чином, кореляційний аналіз за К. Пірсоном засвідчив наявність тісного зв'язку між розвитком операцій виникнення мотивів мовлення й операцій лексико-граматичного структурування висловлювання.

Отримані результати дають підстави стверджувати: чим вищий рівень розвитку мотиваційно-мовленнєвих операцій, тим вищий i рівень розвитку операцій лексико-граматичного структурування висловлювання і навпаки: чим нижчий рівень розвитку мовленнєвих операцій у дітей дошкільного віку, тим нижчий рівень розвитку операцій лексико-граматичного структурування висловлювання, що може негативно впливати не тільки на становлення мовленнєвої діяльності в дітей дошкільного віку, а й на їхній загальний психічний розвиток у межах вікового онтогенезу. 


\section{Дискусії}

Аналіз результатів розвитку в дітей операцій мовленнєвої мотивації та залежних від них операцій граматичного структурування монологічних висловлювань засвідчує їх позитивну динаміку (табл. 6).

Таблиця 6. Порівняльна характеристика динаміки сформованості мовленнєвих операцій у дошкільників віком п'яти і шести років

\begin{tabular}{lcccc}
\hline \multicolumn{1}{c}{$\mathbf{n}=\mathbf{6 3 7}$} & \multicolumn{2}{c}{ Середній показник сформованості мовленнєвих операцій: } \\
& Високи розвитку & \\
\hline До експерименту & 11,1 & Достатній & Середній & Низький \\
Після експерименту & 74,7 & 24,0 & 51,0 & 13,9 \\
\hline
\end{tabular}

Як засвідчено даними таблиці 6, застосовувані психолінгводидактичні заходи дали змогу підвищити більш як на 63,6\% високий рівень розвитку середнього показника сформованості досліджуваних мовленнєвих операцій і відповідно знизити на 41,3 \% середній рівень цього показника. Тим часом недостатній рівень розвитку показника сформованості мовленнєвих операцій дошкільників зменшився більше, ніж у 2 рази (рис. 3).

Середнє значення по вибірці означених показників цілеспрямованої мовленнєвої активності в n'ятирічних дошкільників, як видно 3 даних таблиці 6, перевищує істотно встановлений нами середній рівень їхнього розвитку. В шестирічних дошкільників у результаті здійснення формувальних заходів - середнє вибіркове кожного 3 виділених нами показників мовленнєвої активності перевищує достатній рівень розвитку, наближаючись до високого при рівні значущості: $\mathrm{p} \leq 0,001$ (імовірність похибки - 0,01\%). Отже, застосована система психолінгводидактичних впливів забезпечила очікуваний ефект розвитку цілеспрямованої мовленнєвої активності шестирічних дошкільників, зокрема: операцій виникнення мотиву й лексико-граматичного структурування висловлювань (табл. 7). 


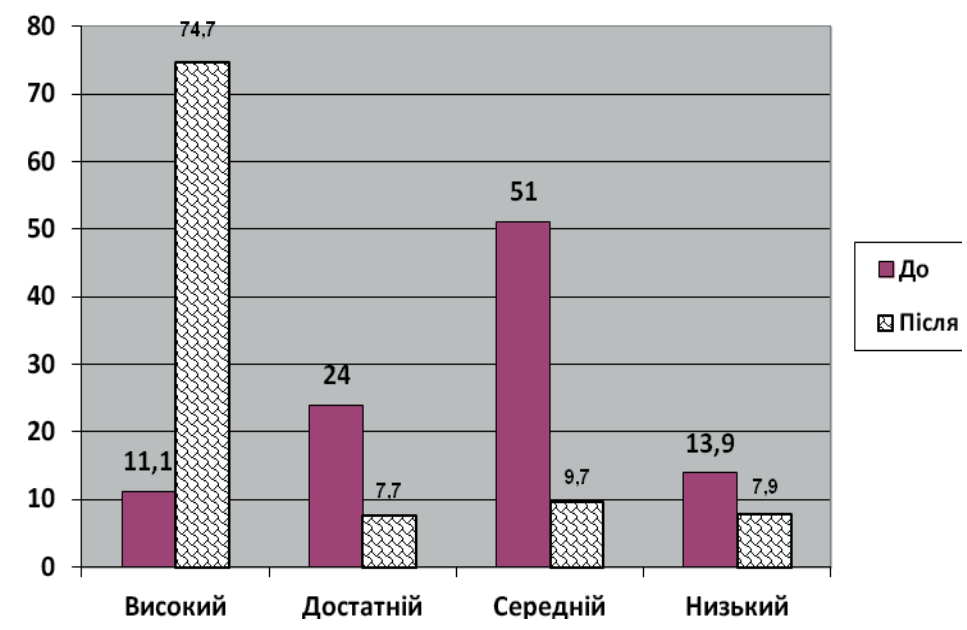

Рис. 3. Порівняльна характеристика сформованості мовленнєвих операцій у дошкільників віком п'яти й шести років (у відсотках)

Таблиця 7. Порівняння показників розвитку цілеспрямованої мовленнєвої активності п’яти- й шестирічних дошкільників (експериментальна група)

\begin{tabular}{|c|c|c|c|c|}
\hline \multirow[b]{2}{*}{ Показники } & \multicolumn{2}{|c|}{$\begin{array}{l}\text { До експерименту } \\
(\mathrm{n}=637)\end{array}$} & \multicolumn{2}{|c|}{$\begin{array}{l}\text { Після експерименту } \\
(\mathrm{n}=637)\end{array}$} \\
\hline & $\begin{array}{c}\text { Середнє } \\
\text { значення по } \\
\text { вибірці: m1 }\end{array}$ & $\begin{array}{c}\text { Стандартне } \\
\text { відхилення: } \\
\text { Q1 }\end{array}$ & $\begin{array}{c}\text { Середнє } \\
\text { значення по } \\
\text { вибірці: m2 }\end{array}$ & $\begin{array}{l}\text { Стандартне } \\
\text { відхилення: } \\
\text { Q2 }\end{array}$ \\
\hline Виникнення мотиву & 2,75 & 0,880 & 3,49 & 0,971 \\
\hline Граматичне структурування & 2,58 & 0,810 & 3,50 & 0,944 \\
\hline $\begin{array}{l}\text { Середній показник розвитку } \\
\text { мовленнєвої активності }\end{array}$ & 2,71 & 0,842 & 3,46 & 0,945 \\
\hline
\end{tabular}

Примітка. Максимальне значення: 4, мінімальне значення: 1. Рівень значущості: $\mathrm{p} \leq 0,001$.

Про високу ефективність розвитку мотиваційного й лексикограматичного компонентів мовленнєвої активності шестирічних дошкільників експериментальної групи в результаті здійснення розвивального впливу свідчать насамперед і встановлені значущі відмінності в показниках розвитку мовленнєвої активності дітей п’яти-шестирічного віку (табл. 8).

Із табл. 8 стає зрозуміло, що в шестирічних дошкільників порівняно 3 дошкільниками п’ятирічного віку - зафіксовано високі статистично значущі (достовірні) зміни за показником 
There is no Target Oriented Speaking Activity without Motivation...

мотивів цілеспрямованої мовленнєвої активності на рівні значущості: $\mathrm{p} \leq 0,001$.

Таблиця 8. Значущі відмінності в показниках розвитку мотивів мовленнєвої активності в дошкільників п'яти- і шестирічного віку після здійснення системних психодидактичних впливів

\begin{tabular}{|c|c|c|c|c|c|}
\hline \multirow[b]{2}{*}{ № } & \multirow[b]{2}{*}{ Показники } & \multicolumn{2}{|c|}{$\begin{array}{l}\text { Експериментальна } \\
\text { вибірка: } \mathrm{n}=637\end{array}$} & \multirow{2}{*}{$\begin{array}{c}\text { Різниця між } \\
\text { середніми } \\
\text { вибірковими: } \\
\text { m1 - m2 }\end{array}$} & \multirow{2}{*}{$\begin{array}{c}\text { Достовірність } \\
\text { відмінностей: } \\
\text { p* }^{*}\end{array}$} \\
\hline & & $\begin{array}{c}\text { Середнє } \\
\text { вибіркове: } \\
\text { m1 }\end{array}$ & $\begin{array}{c}\text { Середнє } \\
\text { вибіркове: } \\
\mathrm{m} 2\end{array}$ & & \\
\hline 1. & Виникнення мотиву & 2,75 & 3,49 & $-0,74$ & 0,001 \\
\hline 2. & $\begin{array}{l}\text { Граматичне } \\
\text { структурування }\end{array}$ & 2,58 & 3,50 & $-0,92$ & 0,001 \\
\hline 3. & $\begin{array}{l}\text { Середній показник } \\
\text { розвитку мовленнєвої } \\
\text { активності }\end{array}$ & 2,71 & 3,46 & $-0,75$ & 0,001 \\
\hline
\end{tabular}

*3а t - критерієм Стьюдента; $\mathrm{t}$ критичне Стьюдента для $\mathrm{p} \leq 0,001: 3,29$

Далі в табл. 9 представлено порівняння показників мовленнєвої активності шестирічних дошкільників експериментальної й контрольної груп, яке засвідчило безумовний розвивальний ефект, отриманий у результаті застосування системи психолінгводидактичних процедур стосовно формування операцій мотивів мовлення й операцій лексико-граматичного структурування висловлювань дітей шестирічного віку в експериментальній групі: якщо сформованість означених операцій мовлення цих дошкільників перевищує достатній рівень розвитку показників мовленнєвої активності, то в дошкільників контрольної групи іiї характеристики навіть не досягають середнього рівня розвитку. Отже, спонтанний розвиток мотиваційно-мовленнєвих і граматичних операцій не дає вищезазначеного ефекту (табл. 9).

Емпіричне дослідження засвідчило, що шостий рік життя дітей дошкільного віку $\epsilon$ сенситивним для розвитку мотивів монологічного мовлення й удосконалення мовної компетенції.

Проведений експеримент дав змогу з'ясувати, що в онтогенезі п'ятирічних дітей мовлення поступово стає цілеспрямованою активністю 3 самостійним мотивом. Проте до 4-5 років мовлення здебільшого стимулювалося ззовні, було 
несамостійною мовленнєвою активністю, оскільки не мало власних мотивів, цүілей, присвячувалося або слугувало іншій діяльності, продукувалося задля задоволення мотивів i досягнення мети інших - не мовленнєвих - видів активності: пізнавальних, ігрових, перцептивних, зображувальних, маніпулятивних, практичних тощо. У цьому контексті висловлювання дітей були не самодостатніми, вони виступали як засіб, знаряддя. Саме завдяки різним, не мовленнєвим видам активності дітей, їхня мовленнєва активність ставала затребуваною, актуальною в різних видах i ситуаціях життєдіяльності.

Таблиця 9. Порівняння показників розвитку операцій мотивів мовлення і лексико-граматичного структурування монологічних висловлювань шестирічних дошкільників ЕГ і КГ

\begin{tabular}{|c|c|c|c|c|c|}
\hline \multirow[b]{2}{*}{ № } & \multirow[b]{2}{*}{ Показники } & \multicolumn{2}{|c|}{$\begin{array}{c}\text { Експериментальна група: } \\
\text { n = } 637 \text { чол. }\end{array}$} & \multicolumn{2}{|c|}{$\begin{array}{c}\text { Контрольна група: } \\
\mathrm{n}=100 \text { чол. }\end{array}$} \\
\hline & & $\begin{array}{c}\text { Середнє } \\
\text { значення по } \\
\text { вибірці: m2 }\end{array}$ & $\begin{array}{c}\text { Стандартне } \\
\text { відхилення: } \\
\text { Q2 }\end{array}$ & $\begin{array}{c}\text { Середнє } \\
\text { значення по } \\
\text { вибірці: m3 }\end{array}$ & $\begin{array}{c}\text { Стандартне } \\
\text { відхилення: } \\
\text { Q3 }\end{array}$ \\
\hline 1. & Виникнення мотиву & 3,49 & 0,971 & 2,62 & 0,951 \\
\hline 2. & Граматичне структурування & 3,50 & 0,944 & 2,28 & 0,877 \\
\hline 3. & $\begin{array}{l}\text { Середній показник розвитку } \\
\text { мовленнєвих операцій }\end{array}$ & 3,46 & 0,945 & 2,60 & 0,950 \\
\hline
\end{tabular}

Примітка. $\operatorname{Max}=4, \min =1$; рівень значущості: $\mathrm{p} \leq 0,001$.

Мовленнєва активність п'ятирічних дошкільників цілковито залежить від сформованості в них мотивів, близьких і зрозумілих їм. Мотивуюча сфера мовлення дітей цього віку охоплює їхні потяги, потреби, інтереси, спонукання, афекти, емоції тощо. Розвиток у них мотивів цілеспрямованої монологічної мовленнєвої активності залежить від того, наскільки своєчасно формуються потреби в ідеальному предметові - смислоформуванні й смислоформулюванні. Становлення системи цілеспрямованих мовленнєвих дій як найвищого ступеня розвитку мовленнєвої активності епігенетично детерміноване розвитком мотивації досягнення, «мотивів-концептів» (Лурия, 1998), - стійких, самостійних, усвідомлюваних мотивів і причин, що лежать в основі мовленнєвих вчинків. 
There is no Target Oriented Speaking Activity without Motivation...

Емпіричне дослідження підтвердило й зафіксовану на етапі констатувального експерименту тенденцію, згідно 3 якою нормі, тобто кожній здоровій (у мовленнєвому сенсі) дитині, властивий індивідуальний нерівномірний розвиток мотиваційних i лексико-граматичних операцій. Дослідження також дало змогу встановити динаміку, вектори й механізми розвитку мотивів мовлення та мовної компетенції в дітей 6-ти років, які вступають до першого класу. Розвиток мотивів цілеспрямованої мовленнєвої активності дітей цього віку відбувається через зміну нестійких, неусвідомлюваних мотивів, полімотивованого мовлення стійкими, самостійними, усвідомлюваними мотивами, мотивацією досягнення. На перших етапах формування в дітей довільної навмисної мовленнєвої активності зовнішньомовленнєві дії спонукаються відразу кількома поєднаними в одне ціле мотивами, близькими й зрозумілими їм. На прикінцевому етапі цілеспрямованого формування один мотив починає задовольнятися комплексом різних за величиною зовнішньомовленнєвих дій: лексикограматичного структурування висловлювань - використання в мовленні різних видів словосполучень, продукування різних типів речень i функціонально-смислових типів мовлення. Діти здійснюють своєрідний вибір мотивів на користь одного 3 них. I це, як правило, смислоформувальні й смислоформулювальні мотиви, а також навчальні мотиви, що актуалізуються бажанням дітей набути вміння висловлюватися логічно, точно, виразно, як це робить вихователь, психолог, диктор, артист та інші. Відтак, почавши виконувати зовнішньомовленнєві дії заради особистіснозначущих мотивів і дидактичних цілей, діти поступово навчаються здійснювати ці дії заради них самих. Поступально утворюються в дошкільників усвідомлювані мотиви-иілі, відбувається зміщення мотиву на мету, а дія набуває статусу самостійної мовленнєвої діяльності. Задля цього у психолінгводидактичних технологіях передбачалася організацію повноцінного, доброзичливого спілкування, що забезпечувало нарощування позитивних емоцій, формування нових мотивів. Завдання комунікативно доцільно говорити підкріплювалася позитивними емоціями через похвалу за кожне правильне висловлювання, через вираження впевненості в мовленнєвих можливостях дітей, через заохочення тощо, а відтак - поступово виформовувався й закріплювався самостійний 
мотив. Саме таким чином мета висловлювання в дітей ставала мотивом. Ці зрушення в мотиваційній сфері зовнішньо проявлялися в тому, що діти отримують задоволення від того, що вміють самостійно визначити мету свого мовлення, добирати доречні слова, висловлюватися комунікативно доцільно, граматично максимально правильно відповідно до усталених норм усного літературного мовлення. Ініціатива будувати розповіді, описи, міркування вже надходила від самих дітей, а не від тих дорослих, хто формує їхнє мовлення, одночасно впливаючи як на збагачення та розвиток асоціативно-смислового поля нейронів головного мозку, так i розширення ментального лексикону дошкільників у цілому.

\section{Висновки}

Як загальний механізм виникнення мотивів, розглядаємо реалізацію ігрових, комунікативних, пізнавальних і рухових потреб дитини в процесі пошукової мовленнєвої активності та перетворення iï об'єктів у мотиви - предмети потреби.

Механізм утворення мовленнєвих мотивів-цілей зумовлює початок у дошкільному онтогенезі нової для дітей - цілеспрямованої активності, тобто мовленнєвої діяльності. Це особлива активність або особливий вид активності, представлений, зокрема, сукупністю мовленнєвих дій, які викликаються одним усталеним мотивом, як правило, значущим для дошкільників. Механізм «зміщення мотиву на мету», або механізм перетворення мети в мотив, тобто трансформація того, що виступало однією 3 цілей, у самостійний мотив, $€$ головним у зміні провідної активності, якою при спеціально організованому формуванні стає цілеспрямована мовленнєва діяльність. Цей механізм знаменує перехід на вищу стадію розвитку мовлення, з якою на етапі старшого дошкільного віку (5-6 років) пов'язана поява таких нових важливих психічних ефектів, як становлення довільності, навмисності, усвідомленості, одночасно 3 якими розвиваються й інші види діяльності, зокрема навчальна, пізнавальна, комунікативна. Сформовані в дітей зовнішньомовленнєві дії $є$ складнішими утвореннями, ніж власне практичні дії. Це - предметні (смислоформулювальні) дії, безпосередньо пов'язані 3 метою цілеспрямованої мовленнєвої 
активності. Вони мають предметний (ідеальний) зміст, є особистим надбанням дітей і зовнішньо виявляється як мовленнєві вміння, які представлені сукупністю вербальних операцій лексико-граматичного структурування мовлення. Зовнішньо мовленнєві дії засвідчують той чи інший рівень розвиненості мовленої компетенції дітей.

Встановлено, чим вищий рівень розвитку мотивації мовлення, тим більш розвиненішими й досконалішими стають операції лексико-граматичного структурування фраз і розгорнутих монологічних висловлювань. Зі зниженням рівнів розвитку операцій виникнення мотивів (від високого до достатнього, середнього й низького) відповідно знижуються й рівні розвитку операцій граматичного структурування та вибору слів за формою. Кожному рівню відповідають особливі психологічні й психолінгвістичні характеристики мовленнєвої мотивації, а також мовленнєвої компетенції.

Емпіричним дослідженням переконливо засвідчено, що операції утворення мовленнєвих мотивів i операції лексикограматичного структурування мовлення, якими вже володіють діти, взаємовпливаючи, зумовлюють поступальне становлення в дітей вищого ступеня монологічної мовленнєвої активності мовленнєвої діяльності й удосконалення мовної компетенції, що $\epsilon$ матеріалізацією латентного стану сформованості як нейронного поля мозку, так і ментального лексикону дошкільника.

\section{Література}

Анохин П.К. Философские аспекты теории функциональной системы : избр. тр. Москва: Наука, 1987. 400 с.

Ахутина Т.В. Вариативность нормы - нейропсихологический и нейролингвистический анализ индивидуальных различий у взрослых и детей. Язык, сознание, культура, этнос : теория и практика : ХІ Всероссийский симпозиум по психолингвистике и теории коммуникации. Москва, 1994. C. $63-65$.

Ахутина Т.В. Нейропсихологический подход к диагностике трудностей обучения. Хрестоматия по нейропсихологии; отв. ред. Е.Д. Хомская. Москва: Ин-т общегуманит. исслед.; Моск. психол.-соц. ин-т, 2004а. С. 779-786.

Ахутина Т.В. Нейролингвистика нормы. Хрестоматия по нейропсихологии; отв. ред. Е.Д. Хомская. Москва: Ин-т общегуманит. исслед.; Моск. психол.-соц. ин-т, 2004b. С. 737-748.

Ахутина Т.В. Нейролингвистический анализ динамической афазии. О механизмах построения высказывания. Москва : Теревинф, 2002. 144 с. 
Без мотиву не буває цілеспрямованої мовленнєвої активності...

Ахутина Т.В., Яблокова Л.В. Нейролингвистический анализ речи первоклассников. Ребенок в современном мире. Санкт-Петербург, 1993. Т. 3. С. 6-7.

Выготский Л.С. Мысль и слово. Психология. Москва: Изд-во ЭКСМО-Пресс, 2000. С. 462-512.

Дубровинская Н.В. Нейрофизиолог в школе. Школа здоровья. 1996. № 1. С. 24-35.

Зимняя И.А. Лингвопсихология речевой деятельности. Москва: Моск. психол.соц. ин-т; Воронеж: НПО «МОДЭК», 2001. 432 с.

Калмикова Л.О. Формування у дітей старшого дошкільного віку мовленнєвої діяльності : діагностико-розвивальний комплекс. Київ : Вид. Дім «Слово», 2016. $384 \mathrm{c}$.

Ковалев Г.А. Психологическое воздействие: теория, методология, практика: дисс. ... д-ра психол. наук : 19.00.01. Москва, 1991. 477 с.

Леонтьев А.А. Основы психолингвистики. 3-е изд. Москва : Смысл; СПб. : Лань, 2003. 287 c.

Леонтьев А.А. Психофизиологические механизмы речи. Общее языкознание: формы существования, функиии, истории языка. Москва, 1970. С. 314-370.

Леонтьев А.А., Рябова Т.В. Фазовая структура речевого акта и природа Планов. Плань и модели будущего в речи. Тбилиси, 1970. С. 27-32.

Леонтьев А.Н. Психологические вопросы сознательности учения. Bопр. психол. понимания; Известия АПН РСФСР. Москва, 1947. Вып. 7. С. 3-40.

Леонтьев А.Н. Речевая деятельность. Основы теории речевой деятельности. Москва, 1974а. С. 21-28.

Леонтьев А.Н. Общее понятие о деятельности. Основы теории речевой деятельности. Москва, 1974b. С. 5-20.

Лисина М.И. Возрастные и индивидуальные особенности общения со взрослыми у детей от рождения до семи лет : дисс. ... докт. психол. наук : 19.00.07. Москва, 1974. 524 с.

Лурия А.Р. Язык и сознание / под ред. Е.Д. Хомской. Ростов н/Д : Изд-во «Феникс», 1998. 416 с.

Миллер Дж., Галантер Е., Прибрам К. Планы и структура поведения / пер. с англ. О. Виноградовой, Е. Хомской ; общ. ред. и предисл. А.Н. Леонтьева, А.Р. Лурия. Москва : Прогресс, 1965. 238 с.

Пылаева Н.М. Опыт нейропсихологического исследования детей 5-6 лет с задержкой психического развития. Вестник Московского университета. Серия 14. Психология. 1995. № 3.

Рубинштейн С.Л. Основы общей психологии. Санкт-Петербург: Питер, 2000. 720 с. Румянцева И.М. Психология речи и лингвопедагогическая психология. Москва : ПЕР СЭ; Логос, 2004. 316 с.

Ушакова Т.Н. Речь: истоки и принципы развития. Москва: ПЕР СЭ, 2004. 256 с.

Хомская Е.Д. Нейропсихология. 4-е изд. Санкт-Петербург: Питер, 2005. 496 с.

Gevarter, C., \& Zamora, C. (2018). Naturalistic Speech-Generating Device Interventions for Children with Complex Communication Needs: A Systematic Review of Single-Subject Studies. American Journal of Speech-Language Pathology, 27(3), 1073-1090. https://doi.org/10.1044/2018_AJSLP-17-0128

Subramaniyan, B., Nagarajan, R., Vaidyanathan, R., et al. (2018). Caregivers' perception of speech and language status and related needs in children with cleft lip and palate. International Journal of Pediatric Otorhinolaryngology, 108, 2225. https://doi.org/10.1016/j.ijporl.2018.02.027

Hui, Min Low, Lay, Wah Lee, \& Aznan, Che Ahmad. (2018). Preparing special education pre-service teachers to address the speech, language and communication 
There is no Target Oriented Speaking Activity without Motivation...

needs of students with ASD: a needs assessment. Speech, Language and Hearing, 21(3), 142-151. https://doi.org/10.1080/2050571X.2017.1336346

Mandak, K., \& Light, J. (2018). Family-centered Services for Children with ASD and Limited Speech: The Experiences of Parents and Speech-language Pathologists. Journal of Autism and Developmental Disorders, 48(4), 1311-1324. https://doi. org/10.1007/s10803-017-3241-y

Mathisen, B., Bennett, S., Lockett, C., Beazley, K., et al. (2016). Talking Matters Bendigo: Engaging Parents Early to Prevent Long-Term Speech, Language and Communication Needs in Preschool-Aged Children. Children Australia, 41(4), 258-264. https://doi.org/10.1017/cha.2016.34

\section{References}

Anohin, P.K. (1987). Filosofskie aspektyi teorii funktsionalnoy sistemyi [Philosophical aspects of the theory of the functional system]. Moscow: Nauka [in Russian].

Ahutina, T.V. (1994). Variativnost normyi - neyropsihologicheskiy i neyrolingvisticheskiy analiz individualnyih razlichiy $u$ vzroslyih $i$ detey [Variability of norm - neuropsychological and neurolinguistic analysis of individual differences in adults and children]. Yazyik, soznanie, kultura, etnos : teoriya $i$ praktika : XI Vserossiyskiy simpozium po psiholingvistike $i$ teorii kommunikatsii - Language, consciousness, culture, ethnos: theory and practice: The Eleven All-Russian Symposium on Psycholinguistics and Communication Theory, (pp. 63-65). Moscow [in Russian].

Ahutina, T.V. (2004a). Neyropsihologicheskiy podhod $\mathrm{k}$ diagnostike trudnostey obucheniya. [Neuropsychological approach to diagnosis of learning difficulties.]. E.D. Homskaya (Ed.), Hrestomatiya po neyropsihologii - Reader for Neuropsychology, (pp. 779-786). Moscow: In-t obschegumanit. issled.; Mosk. psihol.-sots. in-t [in Russian].

Ahutina, T.V. (2004b). Neyrolingvistika normyi. [Neurorolinguistics norms]. E.D. Homskaya (Ed.), Hrestomatiya po neyropsihologii - Reader for Neuropsychology, (pp. 737-748). Moscow: In-t obschegumanit. issled.; Mosk. psihol.-sots. in-t [in Russian].

Ahutina, T.V. (2002). Neyrolingvisticheskiy analiz dinamicheskoy afazii. O mehanizmah postroeniya vyiskazyivaniya [Neurolinguistic analysis of dynamic aphasia. On the mechanisms for constructing an utterance]. Moscow: Terevinf [in Russian].

Akhutina, T.V., \& Yablokova, L.V. (1993). Neyrolingvisticheskiy analiz rechi pervoklassnikov [Neuro-linguistic analysis of the first-graders speech]. Rebenok $v$ sovremennom mire - The child in the modern world. (Vols 3), (pp. 6-7). Saint Petersburg [in Russian].

Vyigotskiy, L.S. (2000). Myisl i slovo [Thought and word]. Psihologiya - Psychology, (pp. 462-512). Moscow: Izd-vo EKSMO-Press [in Russian].

Dubrovinskaya, N.V. (1996). Neyrofiziolog v shkole [Neurophysiologist at school]. Shkola zdorovya - School of Health, 1, 24-35.

Zimnyaya, I.A. (2001). Lingvopsihologiya rechevoy deyatelnosti [Linguopsychology of speech activity]. Moscow: Mosk. psihol.-sots. in-t; Voronezh: NPO «MODEK» [in Russian].

Kalmykova, L.O. (2016). Formuvannya u ditey starshogo doshkilnogo viku movlennevoyi diyalnosti : diagnostiko-rozvivalniy kompleks [Formation in

(C) Kalmykova L., Volzhentseva I., Kharchnko N. \& Mysan I. 
children of the senior preschool age of speech activity: diagnostic-development complex]. Kiyiv: Vidavnichiy Dim «Slovo» [in Ukrainian].

Kovalev, G.A. (1991). Psikhologicheskoe vozdeystvie: teoriya, metodologiya, praktika [Psychological impact: theory, methodology, practice]. Doctor's thesis. Moscow [in Russian].

Leontev, A.A. (2003). Osnovyi psiholingvistiki [Fundamentals of psycholinguistics] (3nd ed., rev.). Moscow: Smyisl; Saint Petersburg: Lan [in Russian].

Leontev, A.A. (1970). Psihofiziologicheskie mehanizmyi rechi [Psychophysiological mechanisms of speech]. Obschee yazyikoznanie: formyi suschestvovaniya, funktsii, istorii yazyika - General linguistics: forms of existence, function, history of language, (pp. 314-370). Moscow [in Russian].

Leontev, A.A., \& Ryabova, T.V. (1970). Fazovaya struktura rechevogo akta i priroda Planov [The phase structure of the speech act and the nature of the Plans]. Planyi $i$ modeli buduscheg o $v$ rechi - Plans and models of the future in speech, (pp. 27-32). Tbilisi [in Russian].

Leontev, A.N. (1947). Psikhologicheskie voprosy soznatelnosti ucheniya [Psychological questions of the consciousness of learning]. Vopr. psikhol. ponimaniya; Izvestiya APN RSFSR - Questions of the psychology of understanding; News from APN RSFSR, 7, 3-40 [in Russian].

Leontev, A.N. (1974a). Rechevaya deyatelnost [Speech activity]. Osnovyi teorii rechevoy deyatelnosti - Fundamentals of the theory of speech activity, (pp. 2128). Moscow [in Russian].

Leontev, A.N. (1974b). Obschee ponyatie o deyatelnosti [General concept of activities]. Osnovyi teorii rechevoy deyatelnosti - Fundamentals of the theory of speech activity, (pp. 5-20). Moscow [in Russian].

Lisina, M.I. (1974). Vozrastnye i individualnye osobennosti obshcheniya so vzroslymi $\mathrm{u}$ detey ot rozhdeniya do semi let [Age and individual characteristics of communication with adults in children from birth to seven years]. Doctor's thesis. Moscow [in Russian].

Luriya, A.R. (1998). Yazyik $i$ soznanie [Language and Consciousness]. Rostov n/D: Izd-vo «Feniks» [in Russian].

Miller, Dzh., Galanter, E., \& Pribram, K. (1965). Plany i struktura povedeniya [Plans and structure of the behavior]. (O. Vinogradovoy \& E. Khomskoy, Trans). Moscow: Progress [in Russian].

Pylaeva, N.M. (1995). Opyt neyropsikhologicheskogo issledovaniya detey 5-6 let s zaderzhkoy psikhicheskogo razvitiya [Experience of neuropsychological study of 5-6 years old children with mental retardation]. Vestnik Moskovskogo un-taMoscow University Psychology Bulletin, 3 [in Russian].

Rubinshteyn, S.L. (2000). Osnovyi obschey psihologii [Fundamentals of General Psychology]. Saint Petersburg: Piter [in Russian].

Rumyantseva, I.M. (2004). Psihologiya rechi i lingvopedagogicheskaya psihologiya [Psychology of speech and linguopagogical psychology]. Moscow: PER SE; Logos [in Russian].

Ushakova, T.N. (2004). Rech: istoki $i$ printsipy razvitiya [Speech: origins and principles of development]. Moscow: PER SE [in Russian].

Homskaya, E.D. (2005). Neyropsihologiya [Neuropsychology] (4nd ed., rev.). Saint Petersburg: Piter [in Russian].

Gevarter, C., \& Zamora, C. (2018). Naturalistic Speech-Generating Device Interventions for Children with Complex Communication Needs: A Systematic 
There is no Target Oriented Speaking Activity without Motivation...

Review of Single-Subject Studies. American Journal of Speech-Language Pathology, 27(3), 1073-1090. https://doi.org/10.1044/2018 AJSLP-17-0128

Subramaniyan, B., Nagarajan, R., Vaidyanathan, R., et al. (2018). Caregivers' perception of speech and language status and related needs in children with cleft lip and palate. International Journal of Pediatric Otorhinolaryngology, 108, 2225. https://doi.org/10.1016/j.ijporl.2018.02.027

Hui, Min Low, Lay, Wah Lee, \& Aznan, Che Ahmad. (2018). Preparing special education pre-service teachers to address the speech, language and communication needs of students with ASD: a needs assessment. Speech, Language and Hearing, 21(3), 142-151. https://doi.org/10.1080/2050571X.2017.1336346

Mandak, K. \& Light, J. (2018). Family-centered Services for Children with ASD and Limited Speech: The Experiences of Parents and Speech-language Pathologists. Journal of Autism and Developmental Disorders, 48(4), 1311-1324. https://doi. org/10.1007/s10803-017-3241-y

Mathisen, B., Bennett, S., Lockett, C., Beazley, K., et al. (2016). Talking Matters Bendigo: Engaging Parents Early to Prevent Long-Term Speech, Language and Communication Needs in Preschool-Aged Children. Children Australia, 41(4), 258-264. https://doi.org/10.1017/cha.2016.34

\section{АНОТАЦІЯ}

Мета статmі полягає в описі: а) виявлених особливостей мотивації розгорнутих монологічних висловлювань і мотивів мовлення дітей п'ятого й шостого років життя в онтогенезі; б) встановленого зв'язку між станом розвиненості мотивів мовлення й станом розвитку операцій лексикограматичного структурування висловлювань, які $\epsilon$ зовнішньомовленнєвим та мають велику пояснювальну силу при тлумаченні процесів оволодіння, а також володіння рідною мовою й усним мовленням. Використано такі методи дослідження, як: а) теоретичні (аналіз наукових джерел, узагальнення проаналізованої літератури та їі систематизація, виокремлення базових положень, на яких грунтується дослідження, формулювання висновків); б) емпіричні (ігрові ситуації, мотивачійно-мовленнєвий скринінг, лінгвістичний контент-аналіз суджень дітей, констатувальний, формувальний і контрольний експерименти, опитування дітей; в) статистичні методи. Студіювання монологічних висловлювань дітей здійснювалося в термінах мовленнєвих операцій. Результати обсервації мовлення дітей розкривають особливості й рівні розвиненості мовленнєвих мотивів в україномовних дітей 5-6 років, своєрідність мотивації мовлення дітей, характерної для кожного з виділених рівнів, засвідчують, що кожній дитині, яка розвивається в нормі, властивий індивідуальний нерівномірний розвиток мотиваційно-мовленнєвих операцій і дій; висвітлюють динаміку, вектори й механізми розвитку мовленнєвих мотивів; демонструють типові стратегії набуття дітьми смислоформулювальних мотивів-концептів, поступального утворення мотивів-цілей, з появою яких відбувається зрушення мотиву на мету, а мовленнєві дії дітей епігенетично набувають статусу самостійної самодостатньої цілеспрямованої мовленнєвої активності; підкреслюють специфріку операцій граматичного структурування дітьми фрраз і розгорнутих монологічних висловлювань та операцій вибору 
Без мотиву не буває иілеспрямованої мовленнєвої активності...

слів за формою; підтверджують кореляційним аналізом взаємозв'язки між мотиваційними й лексико-граматичними операціями.

Ключові слова: мотиви мовлення, мотив-концепт, смислоформулювання, цілеспрямована мовленнєва активність, мовленнєвий онтогенез, мовна компетенція.

Калмыкова Лариса, Волженцева Ирина, Харченко Наталия, Мысан Инна. Без мотива не бывает целенаправленной речевой активности: своеобразие детских монологических высказываний

\section{АННОТАЦИЯ}

Цель статьи заключается в описании: а) выявленных особенностей мотивации развернутых монологчческих высказываний и мотивов речи детей пятого и шестого года жизни в онтогенезе; б) установленной связи между состоянием развития мотивов речи и состоянием развития операций лексико-грамматического структурирования высказываний, которые являются внешнеречевыми и имеют большую объяснительную силу при толковании процессов овладения и владения родным языком и устной речью. Использованы следующие методы исследования: а) теоретические (анализ научных источников, обобщение проанализированной литературы и ее систематизация, выделение базовых положений, на которых основывается исследование, фрормулирование выводов); б) эмпирические (игровые ситуации, мотивационно-речевой скрининг, лингвистический контент-анализ суждений детей, констатирующий, формирующий и контрольный эксперименты, опрос детей в) статистические методы. Изучение монологических высказываний детей осуществлялось в терминах речевых операций. Результаты обсервации речи детей раскрывают особенности и уровни развитости речевых мотивов у украиноязычных детей 5-6 лет, своеобразие мотивации речи детей, характерной для каждого из выделенных уровней, свидетельствуют, что каждому ребенку, который развивается в норме, присущий индивидуальное неравномерное развитие мотивационно-речевых операций и действий; освещают динамику, векторы и механизмы развития речевых мотивов; демонстрируют типичные стратегии приобретения детьми смислофрормулирующих мотивов-концептов, пошагового образования мотивовцелей, с появлением которых происходит сдвиг мотива на цель, а речевые действия детей эпигенетически приобретают статус самостоятельной самодостаточной челенаправленной речевой активности; подчеркивают специфику операций грамматического структурирования детьми фрраз и развернутых монологических высказываний и операций выбора слов по форме; подтверждают корреляционый анализ взаимосвязи между мотивационными и лексико-грамматическими операциями.

Ключевые слова: мотивы речи, мотив-концепт, смыслоформулирование, целенаправленная речевая активность, речевой онтогенез, языковая компетенция. 